\title{
Vegetation histories from the Fijian Islands: Alternative records of human impact
}

\author{
Geoffrey Hope \\ Department of Archaeology and Natural History, The Australian National University \\ Janelle Stevenson \\ Department of Archaeology and Natural History, The Australian National University \\ Wendy Southern \\ Department of Prime Minister and Cabinet, Australian Government
}

\section{Introduction}

The Melanesian high islands of Tertiary and Quaternary volcanic origin provide a natural laboratory for assessing the impact of human settlement on bounded habitats. In Fiji, the three largest islands, Viti Levu, Vanua Levu and Tavieuni, formed a single landmass at glacial times in the Pleistocene, while other high islands occur with a range of isolation from nearest land. Human settlement is known from about 3000 years ago from locations throughout the archipelago. The islands lie at about $16-23^{\circ} \mathrm{S}$ latitude in the tropical southeast trade-wind belt, and exhibit a marked zonation of climate. The eastern and southern windward coast and slopes are humid to hyperhumid and relatively aseasonal, compared with the northwest lee slopes which have a pronounced dry season (though not as extreme as that of Hawaii). Annual rainfall varies from $13,300 \mathrm{~mm}$ at $800 \mathrm{~m}$ on the crestal ridge of Tavieuni, to $880 \mathrm{~mm}$ on the coast of northeastern Vanua Levu.

The vegetation at the time of European arrival reflected that climate, with Sporobolus indicus grasslands or shrublands of disturbance plants (talasiga), as well as woodlands of Casuarina and Santalum widespread on the drier areas of the large islands (Mueller-Dombois and Fosberg 
1998). In many places the talasiga occurs on slopes where the original topsoil layer has been lost through erosion. Dry tropical forests of Fagraea gracilepes, Myrtaceae, legumes and Euphorbiaceae are present today only as remnants. Disturbance is more limited on the southern and eastern (windward) coasts, where forests dominated by Myristicaceae, Calophyllum and Myrtaceae prevail. It is likely that the grasslands and most of the scrubs of Fiji are anthropogenic, since rainfall is sufficient to support at least a dry rainforest throughout the region (Ash 1992). This presumption can be tested by studying sedimentary sequences in swamps and alluvial fills using palaeoenvironmental techniques, as it is possible to compare Holocene pre-human sequences with the post-settlement effects, given that humans arrived relatively late to the Central Pacific (Spriggs 1997).

Swamps often build up deposits over thousands of years and sediment cores from these can be analysed for pollen, phytoliths, charcoal, algae and the various inorganic components such as inwashed soil or carbonates. Samples are taken at close intervals for analysis, allowing a picture of change in the swamp and surrounding landscape over time. Changes in cores can be radiocarbon dated using peat, wood, charcoal or shell samples. These analytical techniques have proven powerful in establishing the impact of phenomena such as cyclones, fires or volcanic ash falls on the stability of the natural vegetation. But they can also discern the effects and timing of human disturbance on the surrounding environment at the same time as establishing the nature of local resources available to human settlements. In addition, the evidence from sedimentary and palynological sequences can be used to examine proposals such as the 'AD 1300 event' argued to have been caused by significant climate shifts (Nunn 2007).

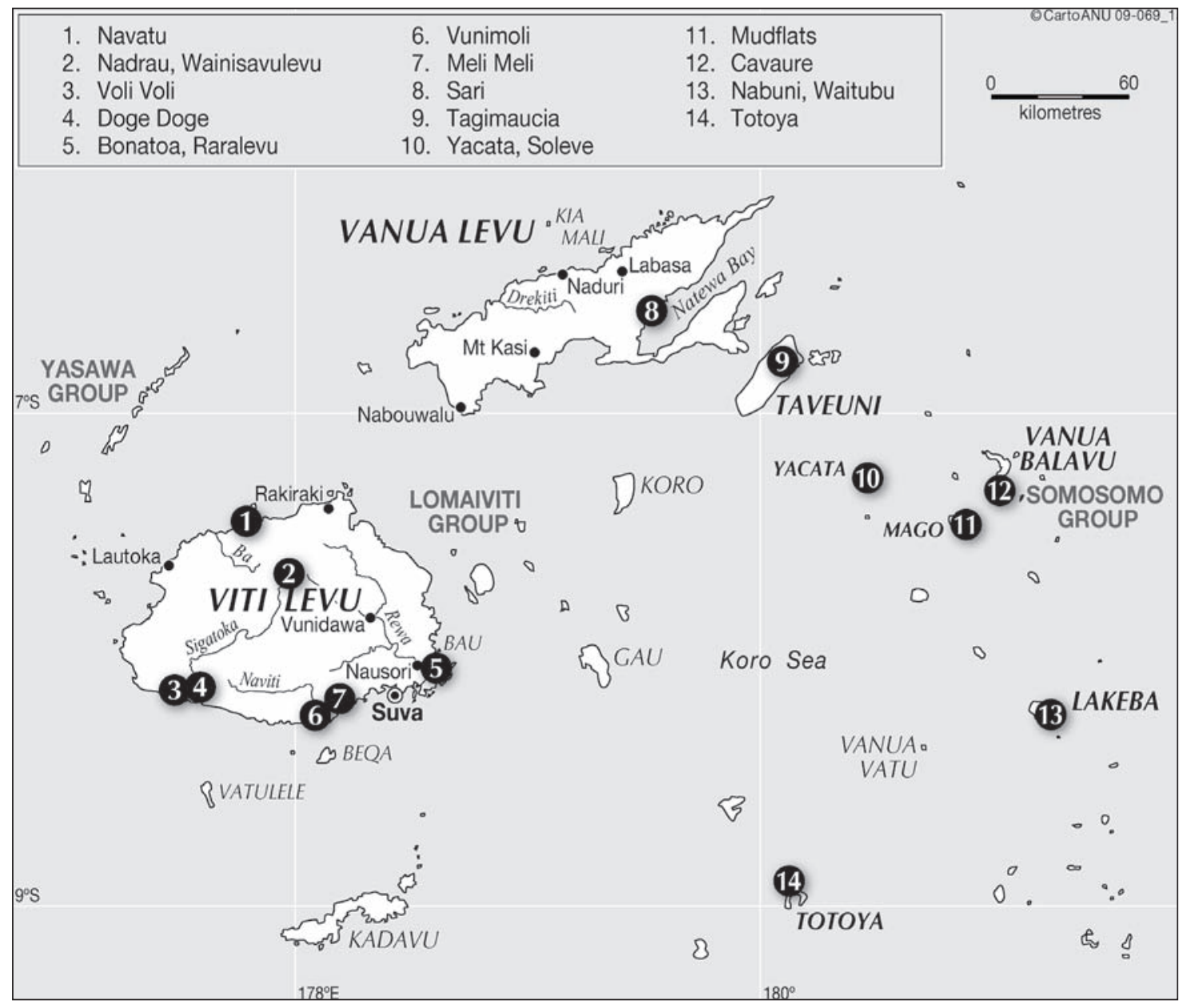

Figure 25. Location of dated mire sequences in Fiji as well as other sites mentioned in the text. 
Six pollen records from Viti Levu and one from Tavieuni were prepared by Wendy Southern in her unpublished $\mathrm{PhD}$ (Southern 1986) and some of her results have been summarised by Geoff Hope (1996) and Hope et al. (1998). Additional sites on Viti Levu and Vanua Levu were collected by Hope and Atholl Anderson in 1996, and in Lau cores were collected by Muriel Brookfield in 1980 (Latham et al. 1983) and by Hope, Patrick Nunn and Geoffrey Clark in 1997 and 2000 (Clark and Hope 2001). Anthony Cole studied six short estuarine cores covering the past 2000 years from the southern island of Totoya for his PhD at Massey University (Cole 1996; Clark and Cole 1997; Clark et al. 1999).

This chapter outlines progress in the interpretation of the palaeoecological record from Fiji. Southern's pioneering work allowed us to develop pollen recognition of important elements in the Fijian flora more quickly than otherwise would have been possible, but a continuing effort by Janelle Stevenson, aided by Mike Macphail (ANU), has been necessary to improve our taxonomic recognition of the complex flora. In all, 23 sites have been sampled and dated, although analyses of some cores are not complete (Table 5, Figure 25). Some critical levels in Southern's sites have been redated using material from her original cores.

In the following discussion, calibrated ages before present (cal. BP) will be used. The records can be divided into three groups, based on the type of sedimentary record and its location.

1. Humid montane mires and lakes with long records.

2. Infilled coastal swamps and alluvial fills.

3. Non-estuarine mires with short records.

Table 5. Sites with dated and pollen analysed sequences from Fiji. Waitubu and Nabuni on Lakeba Island are charcoal records only as the pollen recovered was sparse. The analysis of Cavaure has not been completed.

\begin{tabular}{|c|c|c|c|c|c|c|}
\hline Site name & Altitude & Location & Site type & Setting & Cal. age range (ka) & Analyst \\
\hline Lake Tagamaucia & 680 & Tavieuni & 1 & Fault lake & $0-17$ & W. Southern \\
\hline Wainisavulevu & 720 & Nadrau Plateau, Viti Levu & 1 & Buried peat & $24-29$ & W. Southern \\
\hline Bonatoa Swamp & 4 & Rewa delta, Viti Levu & $2 a$ & Infilled estuary & $0-5.8$ & W. Southern \\
\hline Meli Meli & 1 & Navua delta, Viti Levu & $2 a$ & Infilled estuary & $0-5$ & W. Southern \\
\hline Raralevu & 1 & Rewa delta, Viti Levu & $2 a$ & Infilled estuary & $0-2.2$ & W. Southern \\
\hline Vunimoli & 1 & Navua delta, Viti Levu & $2 a$ & Infilled estuary & $0-3$ & W. Southern \\
\hline Sari & 1 & Natewa Bay, Vanua Levu & $2 b$ & Infilled estuary & $0-6.5$ & J. Stevenson \\
\hline Navatu & 4 & Raki Raki, Viti Levu & $2 b$ & Infilled estuary & $0-4.5$ & J. Stevenson \\
\hline Volivoli & 2 & Sigatoka delta, Viti Levu & $2 b$ & Sand plain lagoon & $0-5.8$ & D. O'Dea \\
\hline Yacata & 2 & Yacata Is, Cakadrove & $2 c$ & Infilled karst & $0-6.5$ & D. O'Dea \\
\hline Soleve & 2 & Kaibu Is, Cakadrove & $2 c$ & Infilled karst & $0-7.9$ & D. O'Dea \\
\hline Mudflat & 2 & Mago Is, Lau & $2 c$ & Infilled karst & $5-7$ & D. O'Dea \\
\hline Cavaure & 0 & Namalata, Vanua Balavu, Lau & $2 c$ & Mangrove karst & $0-6$ & G. Hope \\
\hline Mangrove sites (six) & 1 & Totoya Is & $3 b$ & Infilled estuaries & $0-2.2$ & A. Cole \\
\hline Nadrau Swamp & 680 & Nadrau Plateau, Viti Levu & $3 a$ & Sedge swamp & $0-2.2$ & W. Southern \\
\hline Doge Doge & 8 & Sigatoka valley, Viti Levu & $3 a$ & Sedge swamp & $0-2.2$ & D. O'Dea \\
\hline Nabuni & 23 & Lakeba Is, Lau & $3 c$ & Valley fill & $0.8-2$ & G. Hope \\
\hline Waitubu & 43 & Lakeba Is, Lau & $3 c$ & Valley fill & $0.5-2$ & G. Hope \\
\hline
\end{tabular}




\section{Humid montane mires and lakes}

Lake Tagamaucia (Southern 1986; Hope 1996) is a shallow lake on the windward slope of Tavieuni Island at an altitude of $680 \mathrm{~m}$ and with a modern annual precipitation of about $11,000 \mathrm{~mm}$. Southern obtained a $1340 \mathrm{~cm}$ core of algal muds from the lake and analysed it at $20 \mathrm{~cm}$ intervals. The pollen diagram extends from the late Pleistocene at 17,000 cal. BP through the Holocene to the present. She also analysed the oldest peat in Fiji, a buried deposit at Wainisavulevu, at $720 \mathrm{~m}$ altitude near Nadrau in the centre of Viti Levu. The $2 \mathrm{~m}$ bed of peat and organic-rich clay was exposed about $5 \mathrm{~m}$ below the surface during the construction of a dam. The top of the peat was dated to $27,000 \mathrm{cal}$. BP and the site seems to have been a swamp forest before the last glacial maximum. Twelve levels were counted from this deposit and these can be considered as extending the Tagamaucia record back beyond the Last Glacial Maximum (LGM) as the deposits occur at similar altitudes, although the Nadrau Plateau has somewhat lower precipitation than Tagamaucia. The combined record (Figure 26) provides the longest record of vegetation change from Fiji. Dating of the lacustrine sediments at Tagamaucia suggests steady accumulation until the development of floating sedgelands in the past 1000 years.

Before 15,000 BP the forests are rich in Ascarina and gymnosperms such as Podocarpus, suggesting a mist forest grew at Nadrau and around the lake, but that conditions were slightly drier than present. There are no indications of fire or other evidence for human intervention. In the Holocene Myrtaceae become dominant and Balanops and palms are important in the midHolocene. There is an increase in secondary tree taxa such as Macaranga in the past 1400 years, which may possibly reflect the widespread disturbance of forest at lower altitudes. This remote cloud-bound lake has remained very wet throughout its history and has not attracted any local settlement or disturbance. The humid conditions make the montane forests insensitive to minor changes in rainfall or temperature.

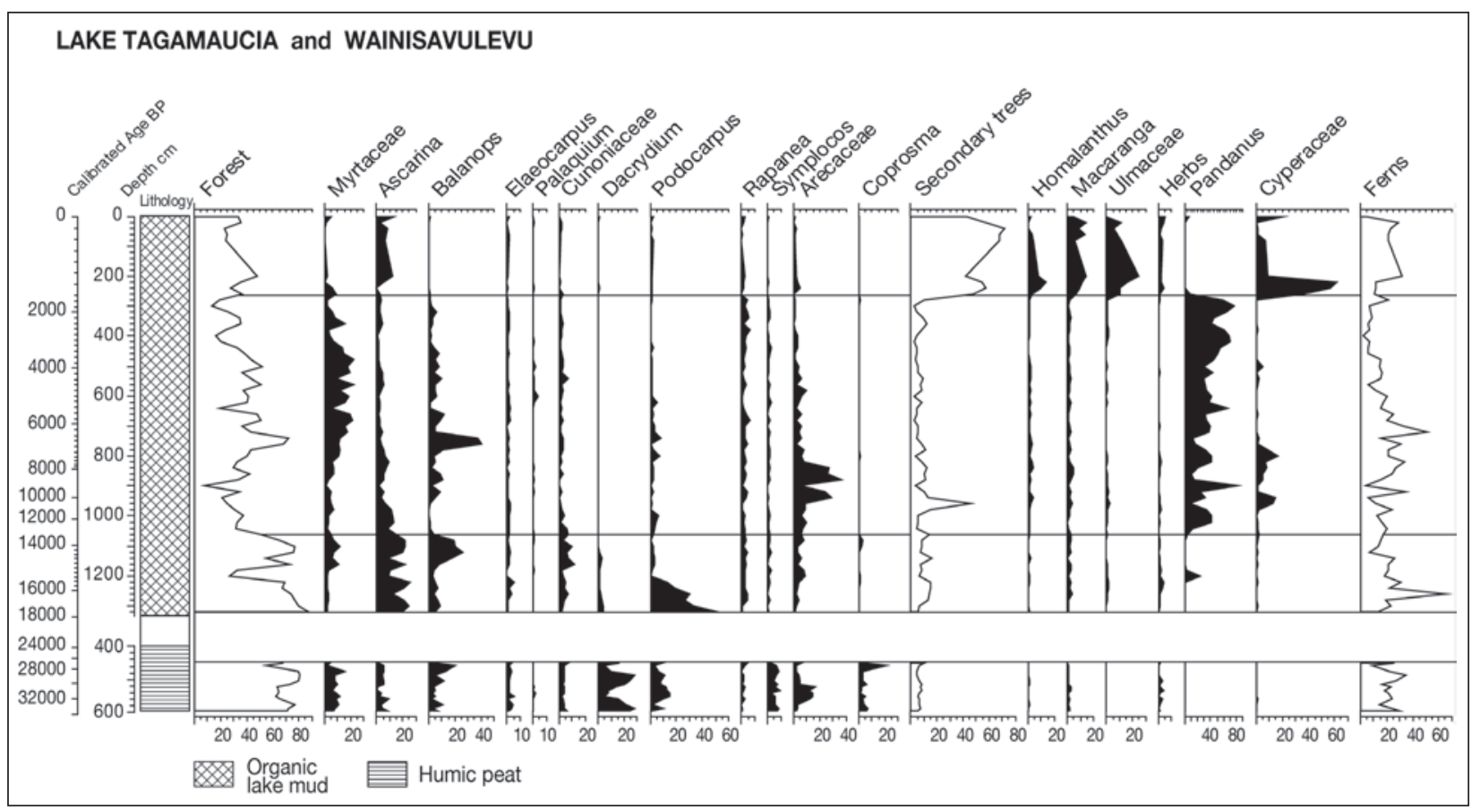

Figure 26. Summary pollen diagram combining Wainisavulevu and Tagamaucia records of Southern (1986). Hollow curves are summarising individual components. The pollen sum is dryland trees, shrubs and herbs. 


\section{Infilled coastal swamps and alluvial fills}

The rise of sea level from 17,000 years ago culminated in a higher-than-present sea-level stand about 6500 cal. BP in the Central Pacific (Dickinson 2001). This process flooded valleys that had cut down to a base level $100 \mathrm{~m}$ below present and formed extensive estuaries. This rise also drowned former coral reefs, providing a phase of high-energy coasts with beach formation. Infilling of embayments, expansion of mangroves and the gradual reappearance of reefs resulted in sedimentation and lake formation along the coastline. In addition, raised base level meant flooding of low-lying areas such as solution hollows in limestones formed by raised former reefs. It is now reasonably well established that sea level has been falling since the mid-Holocene (Dickinson 2001; Nunn and Peltier 2001). This has hastened the transition from estuarine sands and muds to freshwater swamp sediments. Several of these former estuaries and flooded sinkholes have been analysed for records as they span the period of human arrival and subsequent erosion of sediment into the valleys from farmed slopes. The transition is palynologically visible because of the distinctive zonation of mangroves, saline tolerant swamp forest and freshwater species. Fiji has a limited mangrove flora, with species of Rhizophora and Brugieria (Rhizophoraceae) and Lumnitzera (Combretaceae) indicating frequent saline inundation. Saline or brackish flats support Excoecaria agallocha (Euphorbiaceae), which produces a pollen type that is dominant in some pollen diagrams. This could reflect brackish or fresh habitat and interpretation is complicated by the fact that a regrowth forest tree, Homolanthus, has similar pollen. Freshwater swamp woodland is reflected by the Fijian sago palm, Metroxylon vitiense, some Barringtonia species and some Pandanus species. Sedges (Cyperaceae) and waterlilies (Nymphaea) suggest more waterlogged or open pond conditions.

Here we look at the sites in three groups - the high rainfall windward coastal swamps, the seasonally dry southern and northern valley fills, and the infills and swamps in solution hollows in raised reef limestones.

\section{The windward coast of Viti Levu and Vanua Levu}

Southern studied Bonatoa, Raralevu, Meli Meli and Vunimoli swamps in southeastern Viti Levu, claiming evidence for relatively early (>3500 BP) settlement from Bonatoa Bog near the mouth of the Rewa River.

\section{Bonatoa}

Bonatoa is a peat bog today, highly disturbed and near ring forts. The basal sediments at 400 $300 \mathrm{~cm}$ are sandy clays representing aggradation of the Rewa delta and these grade through brown clay to humic peat above $270 \mathrm{~cm}$ as the delta extends seawards. The peat becomes more fibrous above $170 \mathrm{~cm}$, with a $2 \mathrm{~cm}$ band of clay at $160 \mathrm{~cm}$.

The basal zone indicates a well-developed dryland forest of Myrtaceae, Calophyllum, palms, Podocarpus and Palaquium, while sago palm (Metroxylon vitiensis) dominated the swamp (Figure 27). Moderate levels of fine charcoal are present below $290 \mathrm{~cm}$. Above $270 \mathrm{~cm}$ there is a marked decline of sago and surrounding forest elements, coincident with an increase in grasses and sedges and decreasing charcoal. These changes are most likely associated with the growth of a sedge-grass peat swamp at the site. While this may represent a natural decline in the growth of sago, it is noted that human exploitation also prevents sago from flowering and could be a cause of the plant's decline. Charcoal increases again after $200 \mathrm{~cm}$, which Southern (1986) regarded as most likely having an anthropogenic origin. However, she noted that on these grounds the earlier forest decline might also reflect human clearance. She reported a modern age for a bulk sediment section at $275-300 \mathrm{~cm}$, and a date of $2265 \mathrm{cal}$. BP at $240 \mathrm{~cm}$ (Table 6). The chronology 


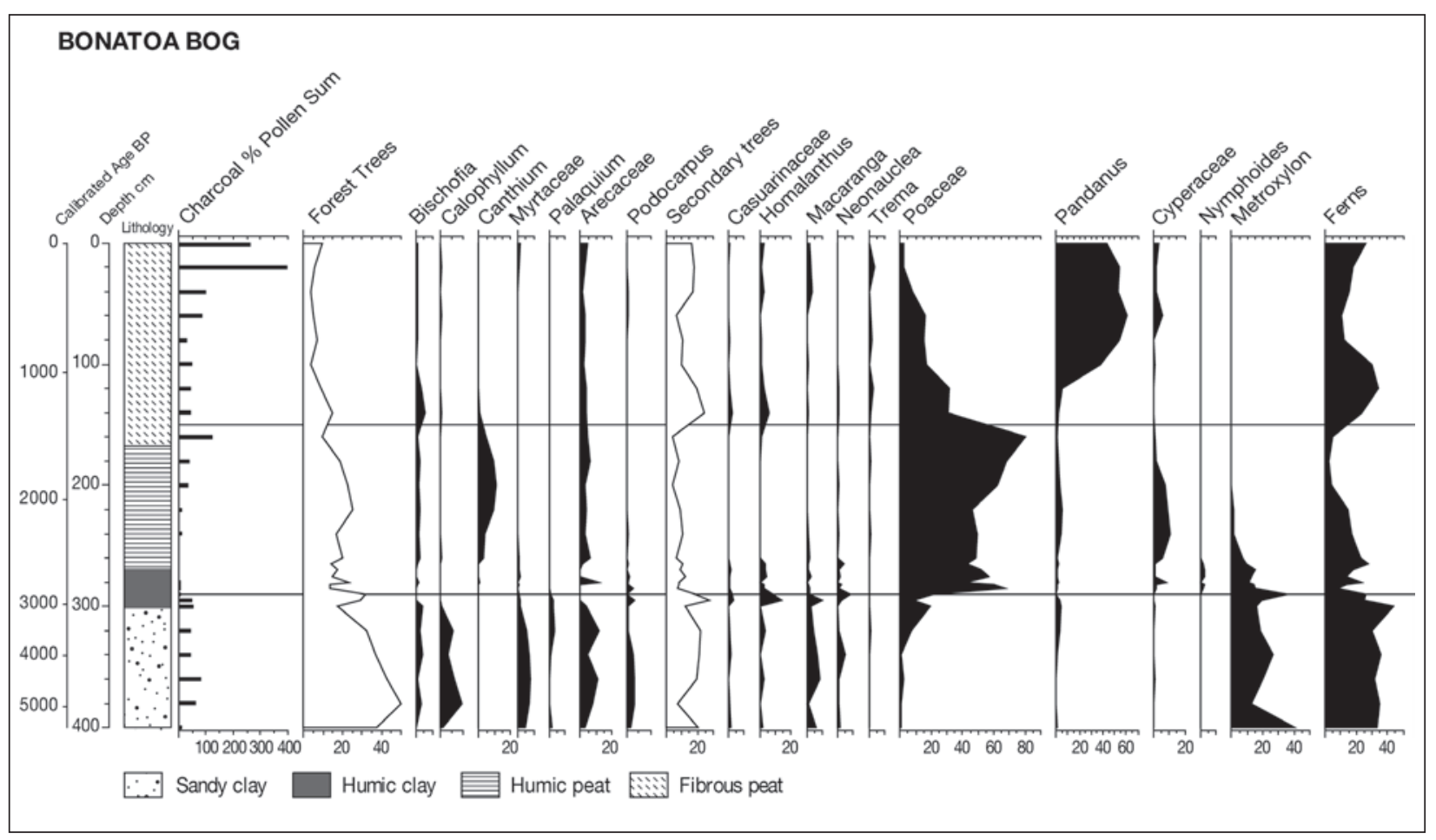

Figure 27. Summary diagram of Bonatoa Bog. Charcoal particles are calculated as a percentage of total pollen. Hollow curves are summaries incorporating individual elements.

Table 6. Radiocarbon dates from Bonotoa.

\begin{tabular}{lllllll}
\hline Sample & Depth $(\mathrm{cm})$ & Date & Cal. age & Cal. age BP & Material Dated & Lab No \\
\hline FV-BON-1 & $140-150$ & $1470 \pm 100$ & 1365 & $1435-1290$ & Bulk peat & ANU 3814 \\
FV-BON-2 & $230-250$ & $2290 \pm 75$ & 2265 & $2365-2165$ & Bulk peat & ANU 3813 \\
FV-BON-4 & 290 & $2710 \pm 40$ & 2805 & $2840-2770$ & ABA fines in silts & 0ZE-471 \\
FV-BON-5 & $380-390$ & $4360 \pm 180$ & 5055 & $5295-4810$ & Bulk organic clay & ANU 3816 \\
\hline
\end{tabular}

made it difficult to guess the real age at $290 \mathrm{~cm}$, where the sediment changes from clay to peat. Pretreated organic material from the original core at $290 \mathrm{~cm}$ has now been redated by AMS to $2800 \mathrm{cal}$. BP, showing that the considerable environmental change at this level coincides in time with the probable appearance of human settlement. Active burning of the swamp only becomes marked around 2100 BP. Within the past 800 years, bracken and Pandanus increase, along with charcoal and secondary trees such as Celtis and Euphorbiaceae. These changes may reflect increasing human use of the wetlands.

Three other swamps on the Rewa and Navua coastal plains were also investigated by Southern (1986).

\section{Raralevu}

Raralevu lies east of the Rewa river in formerly ditched and gardened swampland. The sample section was taken from a buried ditch and consists of $80 \mathrm{~cm}$ of peat overlying grey-brown silty clay. A date of 2030 cal. BP (2070 \pm 90 , ANU 4559) was obtained from a piece of wood at $80-100 \mathrm{~cm}$ depth at the base of the peats.

The early ditch system seems to have been abandoned about 2000 years ago when peat starts to accumulate in the hollow. The record covers 2100 years and is interpreted as showing some forest disturbance with low burning until about 1000 years ago, when more complete 
clearance and local burning occurs. The site may thus record two phases of occupation for wetland agriculture.

\section{Meli Meli}

Meli Meli is an isolated Pandanus-fern swamp $2 \mathrm{~km}$ east of the Navua delta. A $5 \mathrm{~m}$ sequence provides a complete record of the past 5000 years (Table 7). Southern (1986) considered that the basal sands and shell hash $(380-500 \mathrm{~cm})$ started to accumulate in an open estuary around $5000 \mathrm{cal}$. BP. The sands gradually incorporate increasing organic material and grade to humified peat at $300 \mathrm{~cm}$ depth. There is a further transition after $1600 \mathrm{cal}$. BP to fibrous peat.

The record shows a sago palm forest occupied the site in its early stages as at Bonatoa, but it declined and finally disappeared around $1500 \mathrm{cal}$. BP. Bruguiera and other mangroves maintain a presence throughout the record, but the swamp seems to have been an open fernland, with Pandanus and possibly grass, set in a forested catchment. There is insufficient resolution to be certain, but no changes attributable to human disturbance are seen in the record.

Table 7. Radiocarbon dates from Meli Meli.

\begin{tabular}{llllll}
\hline Sample & Depth $(\mathrm{cm})$ & Date & Cal. age & Cal. age BP & Material \\
\hline FV-MEL - & $190-195$ & $1630 \pm 250$ & 1560 & $1302-1820$ & Bulk peat \\
FV-MEL -2 & $415-425$ & $4940 \pm 90$ & 5670 & $5591-5754$ & Coral \\
FV-MEL -3 & $485-500$ & $4400 \pm 90$ & 4960 & $4861-5063$ & Shell hash \\
\hline
\end{tabular}

\section{Vunimoli Bog}

Vunimoli Bog is a tall grassy sedgeland inland of Pacific Harbour, an infilled inlet of the Qaraniqio River, $7 \mathrm{~km}$ west of the Navua River delta that has been developed as a residential and resort area. Four beach ridges underlie the swamp (Shepherd 1990) and lie roughly parallel to the present coastline. They are below present sea level and are buried beneath a peat bog which is about $1 \mathrm{~m}$ deep on the east and up to $4 \mathrm{~m}$ deep on the west. A fifth sand ridge is higher than the others, standing about $2.5 \mathrm{~m}$ above MHWS and overlying buried fibrous peat that formed from before $4500 \mathrm{cal}$. BP until after $3400 \mathrm{cal}$. BP. Shepherd interpreted the front of the ridge as having been eroded by waves, and its formation above the peat argues for a construction event which moved sand shorewards. It may be the result of a storm surge or tsunami after $3000 \mathrm{cal}$. BP.

Southern worked on a shallow section on the northwest edge of Vunimoli swamp. Here, $130 \mathrm{~cm}$ of peat overlies a $20 \mathrm{~cm}$ organic palaeosol with in situ tree stumps built on estuarine sands at around 2820 cal. BP $(2710 \pm 80$, ANU 3808). Like the Rewa sites, Metroxylon is an important element in the early stages of swamp accumulation as part of a hardwood forest that grew on the site. Increasingly peaty conditions eventually forced Metroxylon to decline. The peat section has changes in surrounding forest composition from sub-coastal rainforest to a forest with more secondary species such as Celtis and Trema. This change is associated with an increase in charcoal at $60 \mathrm{~cm}$, with an inferred age of $1700 \mathrm{cal}$. BP. The swamp loses Metroxylon and becomes dominated by sedges and ferns, along with Pandanus. Hence, the Navua sites appear to have had less impact from human disturbance than Bonatoa, and the changes date to $1500-1700$ cal. BP.

\section{Eastern Vanua Levu}

Sari Swamp

Sari Swamp is a sedge-Pandanus swamp located on eastern Vanua Levu near Natewa Bay, a high rainfall location equivalent to the southeastern sites of Viti Levu. The swamp is extensive, infilling a small catchment with an area of 90 ha. A sedgeland lies inland of a complex swamp 
forest of Pandanus, which is separated from the bay by a zone of mangroves and Excoecaria agalloch a woodland. The core site is located within the sedgeland near the southern margin of the swamp. The catchment vegetation is a mosaic of grassland, talasiga and dry rainforest. Dating and pollen analysis shows that the section covers the period since post-glacial sea level rise (Table 8 , Figure 28).

The dating results reveal a gradual reduction in sediment accumulation rate as the site moves from a rapidly accumulating estuarine system to a coastal swamp with a small catchment. The sediment core records the transition from estuarine peaty clays before $4000 \mathrm{cal}$. BP through peaty muds that supported mangrove and sago swamp forest to fibrous peats supporting a freshwater fern swamp with evidence for catchment disturbance in the upper $57 \mathrm{~cm}$ (Figure 28). Charcoal appears consistently after $2700 \mathrm{cal}$. BP, followed by some evidence for forest clearance about $2350 \mathrm{cal}$. BP, at a time when mangrove pollen is also rapidly declining. Charcoal rises dramatically in association with the disappearance of most primary forest taxa after $1700 \mathrm{BP}$. The transition from estuarine to freshwater swamp after $2300 \mathrm{cal}$. BP may reflect sea-level fall or coastal progradation, but the swamp was apparently affected by fire as this change occurred and it became dominated by ferns. The period of clear human impact is contained in the upper $60 \mathrm{~cm}$ of the core, but it may be incomplete.

Table 8. Radiocarbon dates from Sari.

\begin{tabular}{lllllll}
\hline Sample & Depth $(\mathrm{cm})$ & Date & Cal. age & Cal. age BP & Material & Lab No \\
\hline FL-AAS -5 & 70 & $2290 \pm 35$ & 2246 & $2175-2355$ & Organic fines & Wk 20993 \\
FL-AAS - 1 & $125-135$ & $2770 \pm 140$ & 2885 & $2500-3270$ & Organic fines & ANU 10112 \\
FL-AAS -2 & $260-275$ & $3800 \pm 80$ & 4200 & $3980-4420$ & Organic fines & ANU 10101 \\
FL-AAS -3 & $400-418$ & $4870 \pm 140$ & 5615 & $5320-5910$ & Organic fines & ANU 10102 \\
FL-AAS -4 & $588-604$ & $5620 \pm 450$ & 6500 & $5570-7430$ & Organic fines & ANU 10110 \\
\hline
\end{tabular}

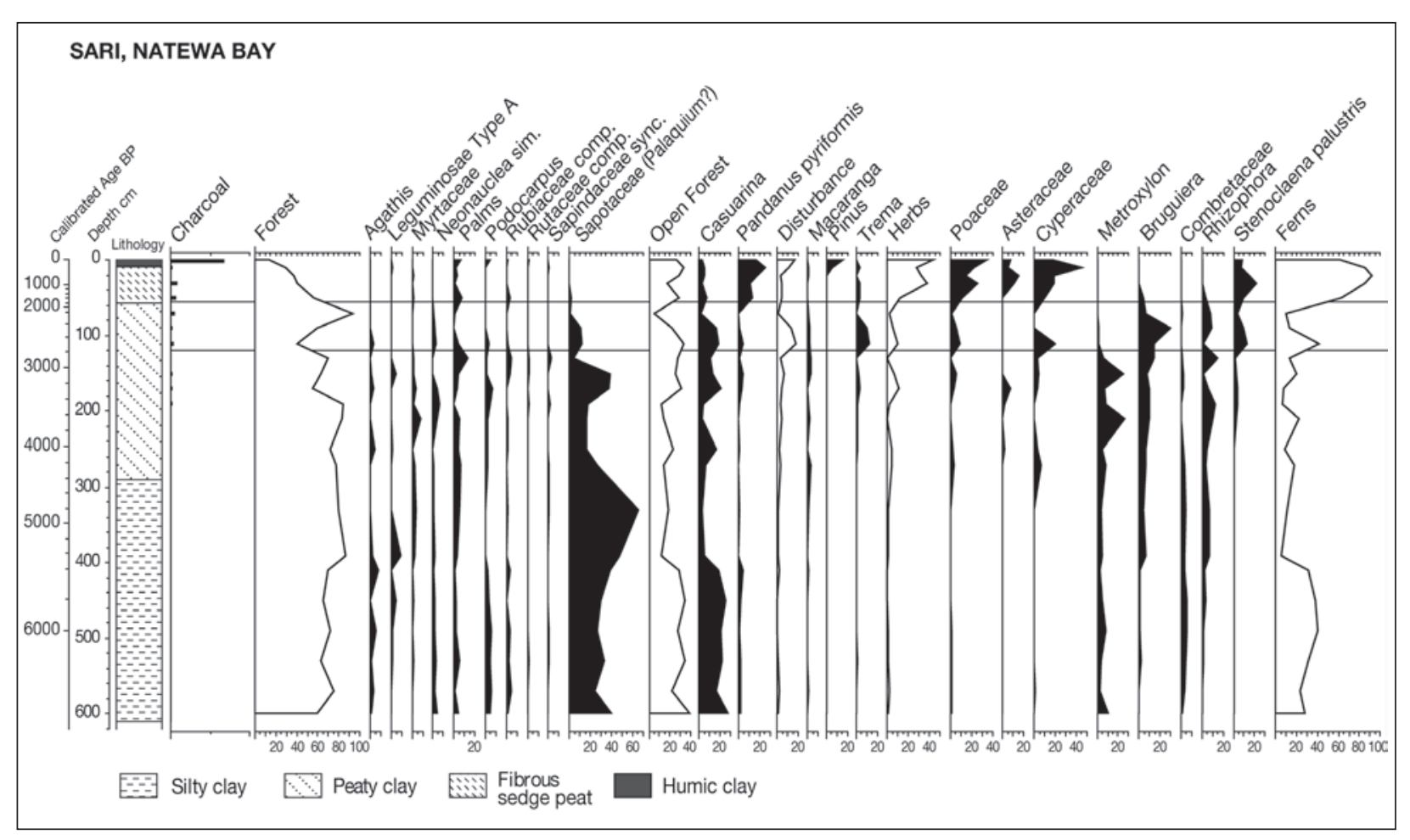

Figure 28. Summary pollen diagram from Sari Swamp, Vanua Levu. 


\section{Totoya Island estuarine cores}

Anthony Cole cored six coastal mangrove swamps around Totoya Island, a crescentic high island south of Viti Levu (Cole 1996; Clark et al. 1998). The cores from Dravawal, Jigo Jigo, Keitera, Lawakile, Udu and Yaro are high-resolution cores $140-295 \mathrm{~cm}$ in depth that extend into estuarine muds and record the decline of already disturbed coastal forests of Maniltoa, Aleurites, Apocynaceae, Calophyllum, Diospyros and Ficus and increasing grass and fernland over the past 1700-2000 years. At some sites the forest is effectively lost by ca. $750 \mathrm{cal}$. BP when there are peaks in charcoal. Charcoal is present throughout all six cores and varying inputs of terrestrial sediment demonstrate continuing disturbance of the catchments.

\section{Estuarine mires on seasonal coasts}

\section{Navatu Swamp}

Navatu Swamp is on the northern coast of Viti Levu $15 \mathrm{~km}$ west of Rakiraki about $200 \mathrm{~m}$ from the sea. A swampy valley floor of red silty clay has built up behind a limestone barrier that may be an old raised reef in which a karst valley developed at a time of lower sea level. Narewa Creek, which drains the steep grassy slopes of the Kroqela Range, spreads across the valley floor. The swamp is at the base of a steep hill that has boulder rock shelters, including the Navatu 17A rock shelter, that have been investigated archaeologically by Gifford (1951) and Clark (2000), with the settlement history extending back at least 2000 years. A $450 \mathrm{~cm}$ section was collected from the floor of the valley about $80 \mathrm{~m}$ from the rock shelter 17A site. The section was composed of black organic sediments buried by $180 \mathrm{~cm}$ of red-brown silts and clays that are a mix of slope wash and alluvium. Samples from the upper $150 \mathrm{~cm}$ were collected by auger, below which D-section cores were recovered (Table 9).

The dates indicate an inversion presumably caused by the incorporation of old charcoal or wood in the slope wash. Movement of a modern humic component or young roots down profile is also demonstrated. The dates on the more organic underlying sediment are presumably more reliable. The site appears to be an infilled estuary that was buried by mixed slope-wash materials sometime after $1200 \mathrm{cal}$. BP to form a sedge swamp (Figure 29). During the estuarine phase, the vegetation is dominated by Excoecaria, and after about $3000 \mathrm{cal}$. BP there are only very low levels of primary rainforest or the dry forest indicator, Casuarina. There is a dramatic change around $160 \mathrm{~cm}$ when mangroves and associated taxa cease and secondary (disturbance) trees, herbs and ferns increase. This follows the change in sedimentation to inorganic clay above $187 \mathrm{~cm}$. Charcoal analysis shows some charcoal over the history of the deposit, but the highest values are all above $160 \mathrm{~cm}$, and suggest the sustained presence of fire within the immediate landscape. The diagram therefore seems to record a disturbed catchment with fire from possible pre-human times but with increased forest loss around 3000 years ago. Local impact on slope vegetation and a possible increased sediment load in Narewa Creek seems to have infilled the peaty swamp after $1100 \mathrm{cal}$. BP. The upper $30 \mathrm{~cm}$ of silts record an increase in herbs and charcoal, probably representing clearance during colonial times. However, increased resolution and dating of individual pieces of charcoal will be required to establish a more reliable chronology.

\section{Volivoli Lagoon}

Volivoli Lagoon is an intermittently flooded area of about 20 ha on the northern side of the beach ridge plain that has infilled the Sigatoka River delta where it meets a steep limestone slope. The sand plain gradually infilled a flooded former valley around 4000-5000 years ago (Anderson et al. 2006). Lapita and later settlement has been recorded from the sand plain (Dickinson et al. 1998), while a cave in the Tertiary limestone to the west above Volivoli has 


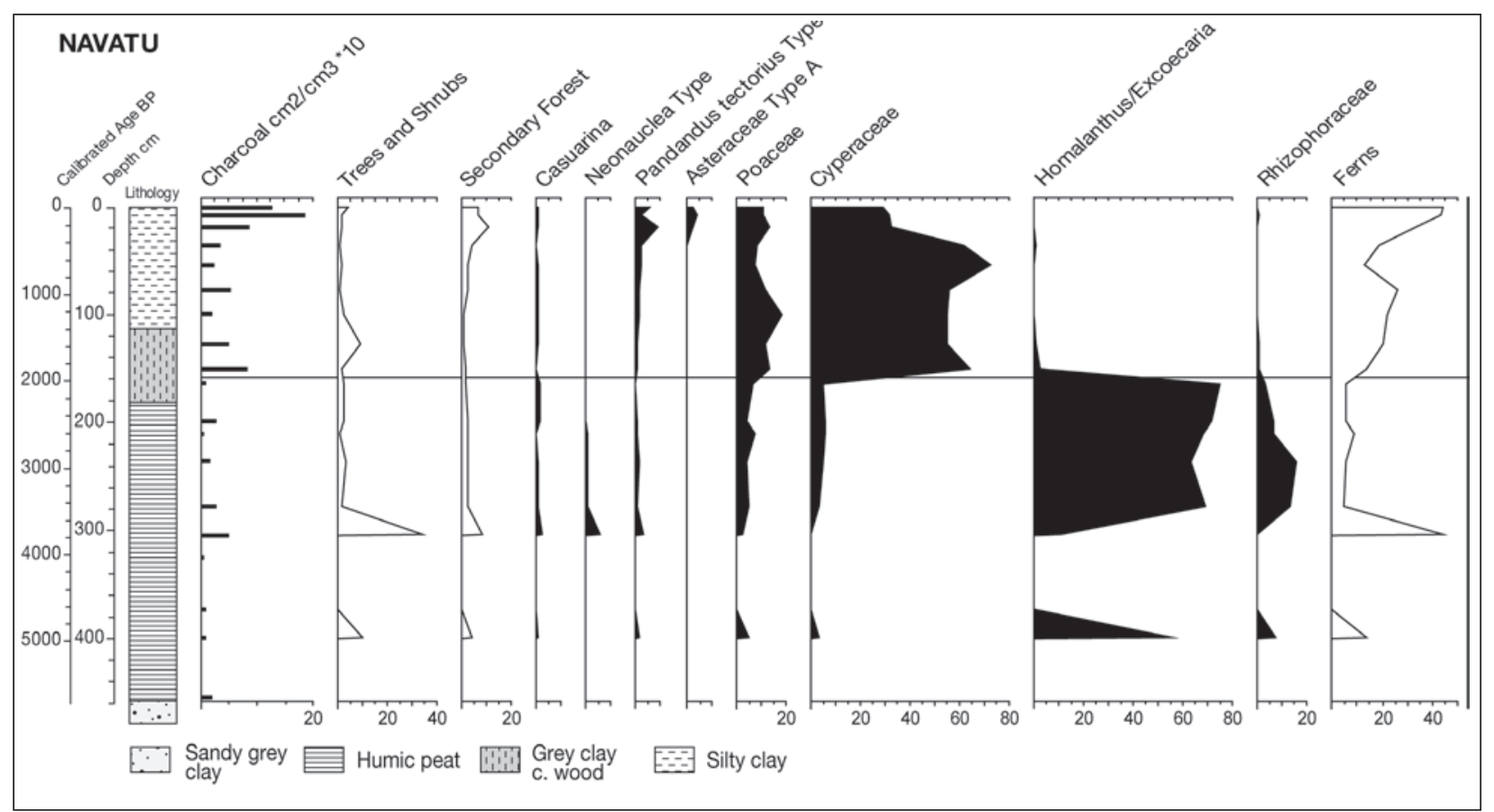

Figure 29. Summary pollen diagram from Navatu.

Table 9. Radiocarbon dates from Navatu.

\begin{tabular}{lllllll}
\hline Sample & Depth $(\mathbf{c m})$ & Date & Cal. age & Cal. age BP & Material & Lab No \\
\hline FV NAV-1 & 160 & $2630 \pm 170$ & 2770 & $2340-3200$ & Peaty clay fines NaOH insoluble from bucket auger & ANU 10762B \\
FV NAV-1 & 160 & $120.1 \pm 5.2$ Modern & 0 & $20-270$ & Organic clay NaOH insoluble fraction & ANU 10762 \\
FV NAV-2 & $192-204$ & $1190 \pm 80$ & 1120 & $960-1280$ & Peaty clay fines NaOH insoluble & ANU 10761A \\
FV NAV-3 & $290-297$ & $3370 \pm 70$ & 3640 & $3450-3830$ & Organic clay fines NaOH insoluble & ANU 10760 \\
\hline
\end{tabular}

provided an extinct fauna including birds and reptiles (see Chapter 3). The outlet from Volivoli Lagoon is blocked by sand ridges and by the Sigatoka sandhills, a dune system derived from transported non-calcareous sands that have built up within the past 3000 years. The lagoon is shown on maps as a permanent lake, but is often dry during the dry season. The flooded area is floored by humic black clay over brown clays which overlie humic peat with wood and deltaic sands. The deepest sections occur close to the steep limestone slope on the east and may occupy former karstic depressions. Samples were taken from a pit wall in 1996, and a D-section core was obtained from 80-205 cm in 1999 to provide a more detailed sediment record (Table 10).

The dating is internally consistent and based on acid-alkali pretreated fine organics, as well as one marine and one freshwater shell date. The age at ca. $50 \mathrm{~cm}$, based on freshwater molluscs hand-picked from the sediment, is older than the extrapolated age-depth curve based on the organic series. At this level, there is a strong clay disturbance signal, raising the possibility that the date is too old due to the presence of 'old' carbon in the lagoon. However, the organic dates indicate that sedimentary and charcoal changes above $140 \mathrm{~cm}$ pre-date known human settlement and clearance. A large correction of 1700 years would have to be applied to the terrestrial peat and shell dates to cause the age depth curve to agree with the likely settlement date, well established on the delta and beach ridges as ca. $2850 \mathrm{cal}$. BP (Dickinson et al. 1998; Burley and Dickinson 2004). If the freshwater shell date from $50 \mathrm{~cm}$ is rejected, then extrapolating the sedimentation rate from surface to the marine shell date at $28 \mathrm{~cm}$ provides an estimate for the base of the 
clay at $87 \mathrm{~cm}$ of $2400 \mathrm{cal}$. BP. The date of $4610 \mathrm{cal}$. BP at $90 \mathrm{~cm}$ may be incorporating older organics, and the underlying sample ages suggest there may be a significant gap in the sediment record around $90 \mathrm{~cm}$. The age model used in Figure 30 assumes an extrapolated age at $90 \mathrm{~cm}$ of $2200 \mathrm{cal}$. BP and continuous slow sedimentation to the $113.5 \mathrm{~cm}$ dated level below. This is admittedly speculative, as the highly inorganic layers between $50 \mathrm{~cm}$ and $80 \mathrm{~cm}$ may have infilled more quickly than the long-term infill rate suggests.

The pollen and sediments indicate an early estuarine lake that was colonised by a backswamp forest of Excoecaria agallocha (but not obligate saline mangroves except possible Combretaceae) near the forested limestone cliffs. The dry forest indicators Casuarina and Neonauclea are present, suggesting a mosaic of drier and wetter forest in the catchment. The Excoecaria forest is replaced above $140 \mathrm{~cm}$ by a freshwater lagoon flora of Nymphoides, with Metroxylon and sedges possibly

Table 10. Radiocarbon dates from Volivoli Lagoon.

\begin{tabular}{lllllll}
\hline Sample & Depth $(\mathrm{cm})$ & Date & Cal. age & Cal. age BP & Material & Lab No \\
\hline FV-V0L-1 & 28 & $1010 \pm 70$ & $590^{*}$ & $490-690$ & Turbo shell & ANU 9925 \\
FV-V0L-2 & $48-52$ & $3610 \pm 110$ & 3530 & $3260-3800$ & Fine shells & ANU 9927H \\
FV0L99-5 & 89.5 & $4040 \pm 50$ & 4610 & $4420-4800$ & Organics & OZF531 \\
FV0L99-6 & 113.5 & $4250 \pm 50$ & 4775 & $4590-4960$ & Organics & OZF532 \\
FV-V0L-3 & $115-122$ & $4640 \pm 80$ & 5350 & $5260-5585$ & Wood & ANU 9926 \\
FV0L99-7 & 140.5 & $4720 \pm 50$ & 5455 & $5320-5590$ & Organics & 0ZF533 \\
FV0L99-8 & 201 & $5120 \pm 60$ & 5790 & $5720-5860$ & Organics & 0ZF534 \\
\hline
\end{tabular}

Notes: Organic fraction between 10 and $125 \mu \mathrm{m}$, with Acid-Base-Acid pre-treatment. Southern hemisphere marine correction of -300yr applied prior to calibration.

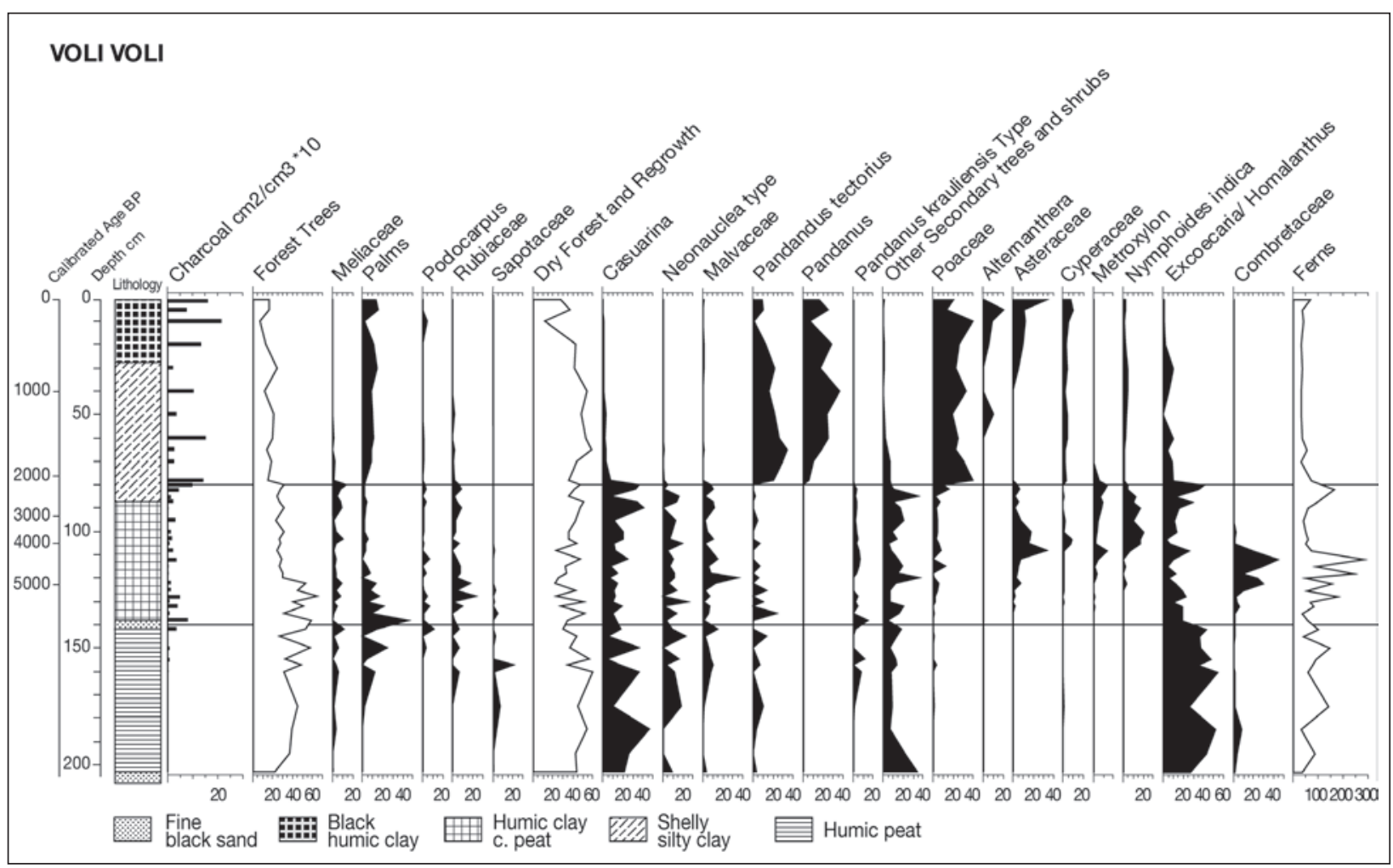

Figure 30. Summary diagram from Volivoli showing increasing charcoal and a transition to inorganic sedimentation. 
reflecting blockage of the drainage by dune development. Consistent burning starts at $145 \mathrm{~cm}$ (5200 cal. BP) and, above this, lenses of clay alternate with peaty clays until $92 \mathrm{~cm}$ when peat formation ceases and the swamp is buried by $60 \mathrm{~cm}$ of clays. Grass and disturbance herbs such as daisies are present in significant quantities once burning begins. The lagoon then becomes more ephemeral and Metroxylon disappears by $80 \mathrm{~cm}$, while Pandanus, sedges, weeds and grass increase. The clay input was derived from slope erosion in the local catchment, and possibly reflects increasing catchment fires. Above $80 \mathrm{~cm}$, grass and Pandanus become dominant and primary forest stabilises at moderate levels. The sediment is more organic above $30 \mathrm{~cm}$ but has oxidised layers, suggesting a return to a fluctuating lagoonal phase but relative landscape stability. The continuing low level of primary forest and high charcoal influx indicates that the forest on the steep slope above the site was being disturbed.

\section{Infilled karstic ponds}

Pleistocene raised reefs are common in Fiji and the limestone is subject to solution that produces a karst landscape called makatea that has jagged ridges, dolines and closed valleys. Where the limestone is close to present sea level the dolines have often developed at times of low sea level to below the present base level. These are now infilled by lagoons, lakes and swamps or are buried by alluvium. Sites investigated at Yacata, Kaimbu, Namalata and Mago islands in eastern Cakadrove and northeastern Lau preserve several metres of organic-rich sediments below 1-3 $\mathrm{m}$ of terrigenous mud. The sites all have similar features in that they occupy karst depressions in raised limestone reefs just one or two metres above present sea level and usually have red or grey silty clay at the surface.

\section{Yacata Pond}

Yacata Island has a central core of volcanic soils with a fringing raised limestone makatea to the north and east. A Holocene beach ridge plain has extended the island by $1 \mathrm{~km}$ to the east where the only village is situated. The Yacata community depends for a permanent water supply on four ponds on the margins of the makatea and volcanics. This line of ponds appears to be a former stream valley of karstic hollows now fed by groundwater and separated by coastal sands from the sea at the southern end. Stratigraphic work was carried out on the northernmost pond at an altitude of around $3.5 \mathrm{~m}$ (Clark and Hope 2001). The basin sediments proved to be variable in depth, although generally deeper close to the volcanic slopes on the west. The basin is now infilled by clays derived from the volcanic interior and supports a sedge swamp which is growing in about $60 \mathrm{~cm}$ of standing freshwater. A core was collected from a point $80 \mathrm{~m}$ from the eastern margin and the clays were found to overlie several metres of organic ooze with small gastropod shells and leaves. The dating resulted in a series of internally consistent ages (Table 11).

The pollen data (Figure 31) show that the site was a deep pond from before 6500 years ago. It is uncertain whether the water was initially saline but Combretaceae pollen is present from the base. The muds on the edge of the pond were probably dominated by Excoecaria agallocha which is saline tolerant. The site has a very long history as a pond with a surrounding coastal forest dominated by Myrtaceae, Macaranga and Casuarina. Low levels of charcoal before $2700 \mathrm{cal}$. $\mathrm{BP}$ suggest that occasional fires occurred on the island in the mid-Holocene. The organic pond sediments are buried by silty clays containing greater quantities of charcoal and a significant increase in grass pollen after $2700 \mathrm{cal}$. BP. Excoecaria (or Homolanthus) remains important until $130 \mathrm{~cm}$ (ca. $1600 \mathrm{cal}$. BP) when the site becomes a sedge swamp. The initiation of slope erosion and a regime of burning and swamp vegetation development starts around $2700 \mathrm{cal}$. BP and the sedge swamp on silty clays is in place by $2050 \mathrm{cal}$. BP. It seems likely that this transition 


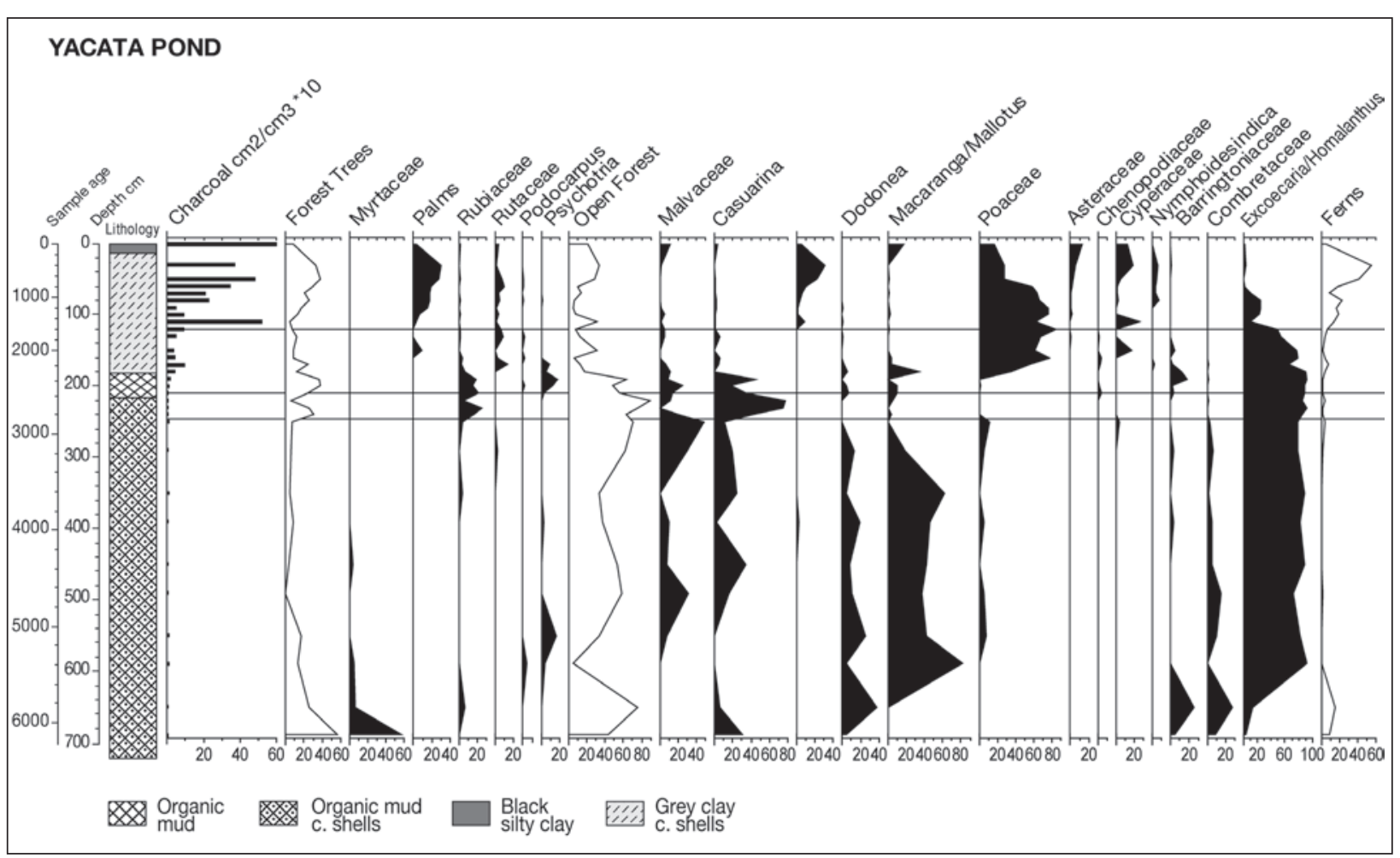

Figure 31. Summary pollen diagram from Yacata Island.

Table 11. Radiocarbon dates from Yacata Swamp.

\begin{tabular}{lllllll}
\hline Sample & Depth $(\mathrm{cm})$ & Date & Cal. age & Cal. age BP & Material & Lab No \\
\hline FL-YAK-1 & $140-158$ & $2000 \pm 70$ & 1980 & $1810-2150$ & Acid insoluble shelly peat & ANU-10812 \\
FL-YAK-7 & 220 & $2618 \pm 34$ & 2650 & $2735-2765$ & Organic fines & Wk-20994 \\
FL-YAK-2 & $235-248$ & $3370 \pm 60$ & 3635 & $3450-3820$ & Organic fines & ANU-10813 \\
FL-YAK-6 & $731-745$ & $5670 \pm 470$ & 6485 & $5470-7500$ & Organic fines & ANU-10821 \\
\hline
\end{tabular}

is anthropogenic as it overlaps with the established archaeological record and the lake may have been an attractive resource for the first colonists. The post-settlement vegetation alternated between grass and fern dominance, and weed pollen (Asteraceae, Caryophyllaceae) is prominent throughout but increases to the present. Pollen from Ivi (Tahitian chestnut, Inocarpus fagiferus) is rarely preserved but this nut tree is prominent around the margins of the swamp today.

Soleve 2

Three swampy karst hollows (Sol 1-3) on Kaibu Island, a few kilometres east of Yacata, hold water after rain, one forming a permanent lagoon (Sol 3). These sites lie near the western coast at around $4 \mathrm{~m}$ altitude at the transition of the makatea to the volcanic soils and are accessible from garden areas. The swamp area may have been the main freshwater source in the past, and wells are present in two of the three basins. The basins are surrounded by a pure stand of Ivi trees about 1.2 ha in extent, growing in moist dark brown mud. The least disturbed hollow, Soleve 2, was cored, giving a similar stratigraphy to Yacata of clay overlying organic muds and clayey muds.

The pollen results show that disturbance and burning is associated with the appearance of clays above $350 \mathrm{~cm}$ (Clark and Hope 2001). Unfortunately, the chronology contains a significant inversion and the cause of the young age at $387 \mathrm{~cm}$ is unknown (Table 12). The initial clay input 
increases gradually above this level, representing the infill of a shallow lake which was finally buried by terrestrial sediment from the local catchment. If related to human settlement, this seems to represent less intensive use of the swamp catchment over a longer time than in the case of Yacata Swamp.

Table 12. Radiocarbon dates from Soleve 2.

\begin{tabular}{lllllll}
\hline Sample & Depth $(\mathbf{c m})$ & Date & Cal. age & Cal. age BP & Material & Lab No \\
\hline FL-KMB-2 & $218-230$ & $2690 \pm 240$ & 2775 & $2160-3390$ & Fine organics in clay & ANU 10819 \\
FL-KMB-4 & $380-395$ & $1240 \pm 340$ & 1230 & $620-1840$ & Organic muds, fine fraction & ANU 10814 \\
FL-KMB-10 & $771-779$ & $7040 \pm 70$ & 7840 & $7700-7980$ & Organic muds, fine fraction & ANU 10820 \\
\hline
\end{tabular}

\section{Mudflat, Mago Island}

The volcanic central part of Mago Island is drained eastwards by a small stream (Waitambo River) to the Butoni mudflat where the stream sinks into a doline in the marginal makatea. Coring at four locations on the plain established that the red clays overlie $150 \mathrm{~cm}$ to $320 \mathrm{~cm}$ of sticky grey clays with fragments of charcoal. These slope-wash sediments bury up to $5 \mathrm{~m}$ of peats and shelly organic lake muds with abundant wood. The main sampled site, MMF-1, lies $25 \mathrm{~m}$ southwest of the road bridge over the stream, at the lower end of the catchment. Similar sequences were found both closer to the exit doline and $1 \mathrm{~km}$ upstream, confirming the widespread nature of the deposit. Pollen and charcoal analyses were made on this sequence.

The swamp-lake phase from ca. 7500 to 5000 years ago is dominated by swamp forest that includes Araliaceae, Myrtaceae, Sapotaceae and Rubiaceae. Ferns are abundant but sedges are intermittent and no mangroves or Excoecaria are present. Low levels of charcoal are scattered through the section. Clay increases above $410 \mathrm{~cm}$, associated with increased disturbance taxa such as Macaranga. Inorganic clays above $240 \mathrm{~cm}$ contain increased charcoal, together with grass, monolete ferns and Asteraceae, while forest elements decline abruptly. The major change in sedimentation processes at the site is possibly the result of changes to the vegetation cover of the island from forest to talasiga, which released clays that buried a forested peat swamp into which only minor sediment inputs from the surrounding catchment had occurred over previous centuries. The probable cause is human clearance for gardens throughout the catchment, an event that must post-date the Lapita settlement known from the island (Clark et al. 2001). However, the bulk date of $5580 \mathrm{cal}$. BP from $280 \mathrm{~cm}$ is much older than the likely date of human colonisation and may result from the incorporation of older organics in the clay (Table 13). If so, there may have been loss of the upper parts of the swamp sediments due to erosion. The appearance of red mottling around $185 \mathrm{~cm}$ depth suggests a minor soil formation event which indicates that the catchment erosion has had at least two phases. The most recent was possibly caused by the establishment of plantations and the growth of cotton and sugarcane on the riverine plain in the 19th century (Ward 2002).

The raised reef karst hollow sites so far investigated are all on the small islands of northeast Fiji but suitable sites occur elsewhere, such as saline lakes containing anoxic muds on Vanua Levu and Lakeba Island. These sites have been reported as important sources of fish as the muds are periodically disturbed, causing all the fish to surface due to anoxia. Additional karst hollows have been tested on Vanuabalavu and on nearby Namalata Island, where a $700 \mathrm{~cm}$ core from Cavaure sinkhole has been shown to preserve a 6500 year record of saline muds that contain marine diatoms. 
Table 13. Radiocarbon dates from Mudflat-1.

\begin{tabular}{lllllll}
\hline Sample & Depth $(\mathrm{cm})$ & Date & Cal. age & Cal. age BP & Material & Lab No \\
\hline FL- MMF1-1 & $272-288$ & $4920 \pm 130$ & 5580 & $5320-5930$ & Organics & ANU 11032 \\
FL- MMF1-2 & $350-365$ & $5380 \pm 200$ & 6145 & $5720-6570$ & Organics & ANU 11033 \\
FL- MMF1-3 & $740-755$ & $6810 \pm 150$ & 7685 & $7430-7940$ & Organics & ANU 11034 \\
\hline
\end{tabular}

\section{Non-estuarine mires with short records}

\section{Nadrau Swamp}

Southern (1986) carried out extensive coring across a 150 ha sedge swamp at ca. $680 \mathrm{~m}$ on the Nadrau Plateau of Viti Levu. The site lies on the main divide of the island close to the margin of humid forest and the anthropogenic grasslands of the dry side of the island. The swamp, dominated by grasses and sedges, has colonised a side valley that was impounded behind a stream levee. It contains $2-5 \mathrm{~m}$ of fibrous sedge peat over $2 \mathrm{~m}$ of brown silty clay. A few remnant trees from former rainforest cling to the slopes around the swamp.

The basal date (Table 14) marks the start of the development of peat on an inorganic alluvium. The pollen diagram shows a rapid decline in a montane forest of Dacrydium, Cunoniaceae in the basal alluvium and after ca. $2200 \mathrm{cal}$. BP there is little change to the surrounding cleared area (Hope et al. 1998). Charcoal is abundant throughout and supports the pollen evidence for clearance and burning that was already occurring at the base of the section, which has an estimated age of $2200 \mathrm{cal}$. BP. People may have played a role in forming the peatland by causing slope erosion that blocked the valley and by increasing the run-off to the swamp by clearing land in the swamp catchment. Around $750 \mathrm{cal}$. BP the swamp has increased sedges and ferns and there is a slight increase in forest cover, suggesting wetter conditions or reduced impact.

Table 14. Radiocarbon dates from Nadrau Swamp.

\begin{tabular}{lllllll}
\hline Sample & Depth $(\mathrm{cm})$ & Date & Cal. age & Cal. age BP & Material & Lab No \\
\hline FV NDR-1 & 182 & $850 \pm 47$ & 745 & $685-800$ & Pollen sample & Wk 21522 \\
FV NDR-2 & $472.5-482.5$ & $2090 \pm 110$ & 2045 & $1924-2168$ & Bulk peaty clay & ANU 3810 \\
\hline
\end{tabular}

\section{Doge Doge Swamp}

About $12 \mathrm{~km}$ from the mouth of the Sigatoka River in southwestern Viti Levu, Parry (1987) described a peat swamp in a tributary valley south of the Nasuto ridge and $400 \mathrm{~m}$ west of Nadrala village. Two sedgelands occur on separate small tributaries of Nadrala Creek, both evidently fed by springs at the base of the northern ridge. A swamp forest occupies part of the eastern swamp. The western swamp is about 5 ha in extent and dominated by a cutting sedge (Cyperus) with a general water depth of about $45 \mathrm{~cm}$. The sedge Elaeocharis sp., a shrub Melastoma and small pools supporting waterlilies also occur. A $320 \mathrm{~cm}$ core was recovered from the northeastern end of the swamp, with a radiocarbon date returning an age of $2000 \mathrm{cal}$. BP at $215 \mathrm{~cm}$ (Table 15).

The pollen diagram (Figure 32) shows that forest had already declined at the base of the deposit, during a time of rapid local sedimentation, while grass and charcoal is increasing, suggesting continuous human disturbance of the surrounding vegetation. Casuarina, palms and secondary trees such as Trema increased after $2100 \mathrm{cal}$. BP as the immediate slopes stabilised. The swamp first supported Metroxylon, but later may have become a pond, evidenced by the replacement of sago palm by a woodland of Excoecaria which persists until very recent times, 


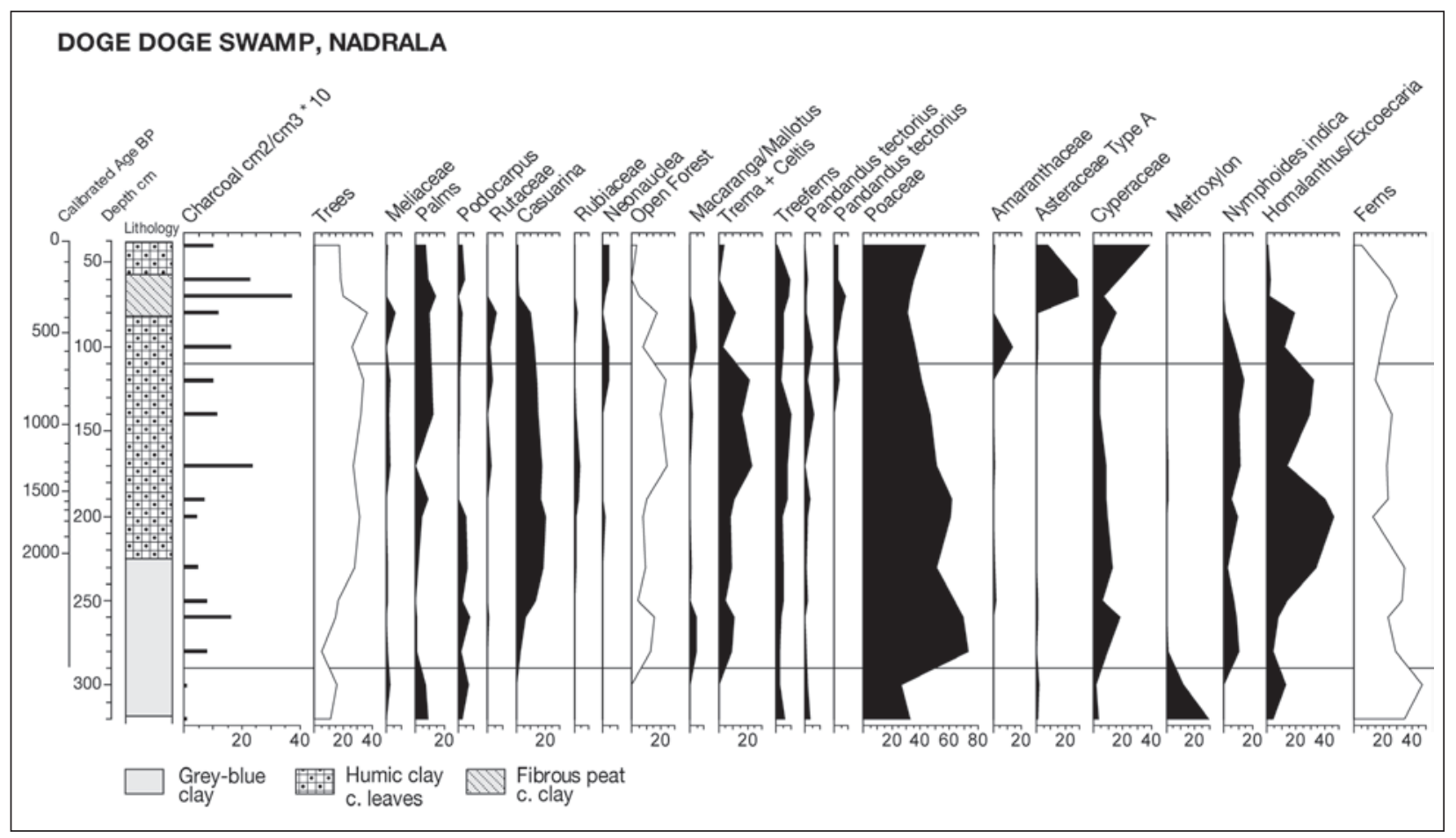

Figure 32. Summary pollen diagram from Doge Doge Swamp, Nadrala.

Table 15. Radiocarbon dates from Doge Doge Swamp.

\begin{tabular}{lllllll}
\hline Sample & Depth $(\mathrm{cm})$ & Date & Cal. age & Cal. age BP & Material & Lab No \\
\hline FV NAD1 & $165-178$ & $1330 \pm 130$ & 1240 & $960-1520$ & Organic fines & ANU 10104 \\
FV NAD2 & $205-225$ & $2090 \pm 160$ & 2050 & $1630-2470$ & Organic fines & ANU 10103 \\
\hline
\end{tabular}

when the swamp became a sedgeland. There is a marked decline in forest after $700 \mathrm{cal}$. BP. Doge Doge is a swamp confined by stream levee building that may have resulted from deforestation in the surrounding hills, which seem to have been entirely cleared by around 2000 BP. This site is effectively anthropogenic, and Nadrala Creek itself is graded to the large flood plain of the Sigatoka, suggesting that the latter might have been constructed during a period of great sediment supply.

\section{Nabuni and Waitubu}

Muriel Brookfield cored several swamps on Lakeba Island in the Lau Group in 1978 and two were selected for charcoal analysis in addition to carbon dating. Nabuni and Waitubu are swampy areas at $23 \mathrm{~m}$ and $43 \mathrm{~m}$ altitude respectively in valleys on the eastern side of Lakeba. In both, about $1 \mathrm{~m}$ of slightly peaty brown clays rich in charcoal overlie 5-6 $\mathrm{m}$ of red clays with scattered charcoal that infill valley lines. Monolete fern spores and grass pollen were found throughout but in low numbers below the upper horizon (Latham et al. 1983). Table 16 gives the radiocarbon dates, which largely reflect the age of charcoal fragments and hence may slightly overstate the age of the fires.

These records are evidence for a massive deforestation event around $2000 \mathrm{cal}$. BP in which several metres of sediment were deposited. The dating inversions probably indicate secondary remobilisation of sediment, with older sediments burying younger. The pollen data indicates that only regrowth vegetation was present and the charcoal demonstrates that fire was the cause of the instability. 
Table 16. Dating the Waitubu (WTB1) and Nabuni (NMB1) valley fills on Lakeba Island.

\begin{tabular}{lllllll}
\hline Sample & Depth $(\mathbf{c m})$ & Date & Cal. age & Cal. age BP & Material & Lab No \\
\hline WTB1-1 & $82-100$ & $945 \pm 170$ & 896 & $738-1054$ & Charcoal, peat & GX5616 \\
WTB1-2 & $225-240$ & $1505 \pm 165$ & 1440 & $1280-1603$ & Charcoal & GX5617 \\
WTB1-3 & $315-335$ & $1910 \pm 210$ & 1870 & $1622-2121$ & Charcoal & GX 4851 \\
WTB1-4 & $460-490$ & $1820 \pm 150$ & 1755 & $1582-1925$ & Charcoal & GX5618 \\
WTB1-5 & $618-638$ & $1805 \pm 140$ & 1735 & $1576-1892$ & Charcoal & GX 4852 \\
NMB1-1 & $90-105$ & $1645 \pm 105$ & 1560 & $1435-1685$ & Charcoal & GX5619 \\
NMB1-2 & $125-150$ & $1005 \pm 145$ & 940 & $790-1090$ & Charcoal & GX5620 \\
\hline
\end{tabular}

\section{Discussion}

\section{Prehuman landscapes and vegetation}

The large islands of Fiji were cooler but possibly slightly drier during glacial times. Lower sea levels tripled the land area of the largest island and probably resulted in enhanced differentiation between the windward and dry sides. While Pleistocene records from Fiji are restricted to the orographic high rainfall areas, vegetation histories from southern New Caledonia (Hope and Pask 1998; Stevenson et al. 2001; Stevenson and Hope 2005) point to natural fire and the periodic expansion of disturbance scrubs (maquis) on several occasions before this, suggesting climate shifts towards greater seasonality and possibly lower rainfall. Latham (1986) infers from terrace building and the formation of soil calcretes that rainfall on the dry side of New Caledonia was 30\% lower than present at 25,000 cal. BP, and Hope and Pask (1998) interpret their New Caledonia records as indicating that cyclones were rare in the Pleistocene compared with the Holocene. However, Fiji is somewhat more tropical than New Caledonia and the changes there may have been less distinct.

The rapid rise of sea level from around 16,000 to 7000 cal. BP changed Fiji by drowning reefs, separating islands and flooding into river valleys (Dickinson 2009). The stratigraphies of all dated pollen sites in Fiji are shown in Figure 33, which demonstrates that many of them develop from estuaries to peat swamp under sedge or tree cover. Some sites record burial by slope wash after $2200 \mathrm{cal}$. BP. With the stabilisation of sea level around $7000 \mathrm{cal}$. BP, Fiji had a phase of beach-ridge development and estuarine infilling because the absence of mature coral reefs led to a generally higher energy coastline. As reefs developed and interfered with wave patterns, sandy coasts became lagoonal and mangroves colonised the calmer strandlines. This process took variable time to complete, but by $2000 \mathrm{cal}$. BP, reefs had reached an equilibrium, with sea level and coasts largely protected. Coastal stabilisation was accelerated by small falls in sea level around 4500 and 2200 years ago, which offset any slight isostatic sea level rises due to shelf loading by the sea. Dickinson (2009) suggests that the fall improved the liveability of some islands, particularly atolls.

At the time of first colonisation around $3000 \mathrm{cal}$. BP there were more sandy beaches and slightly less extensive but rapidly growing productive reefs. The estuaries led further inland to dense mangrove stands and swamps with abundant sago palms. Wild coconuts were most likely present along strands and sand plains. If the core chronologies are correct, the pre-3000 cal. BP records from two seasonal sites, Volivoli and Navatu, show a distinct increase in charcoal after 4500 years ago. More significantly, forest cover was evidently not continuous around either site, as herbs, grass and secondary taxa are present. This raises the possibility that the dry side of Viti 
Levu was partly open with a mosaic of forest and savannah patches in the mid-Holocene. Better sites with reliable dating will be needed to check this, but based on current experience, fire would have been caused by lightning and could have spread most easily during drought periods associated with El Niño phases. Fire certainly occurred before human arrival, as shown by the site at Keiyasi on the middle reaches of the Sigatoka River (Nunn et al. 2001). Here, bands of charcoal occur near the base of a $6 \mathrm{~m}$ terrace and are dated to around $5400 \mathrm{cal}$. BP $(4630 \pm 60$, NZA-12539). Nunn considers that the substantial sediment mobilisation may indicate a widespread dry phase at that time. Even wet coastal sites such as Bonatoa contain mid-Holocene charcoal, but some sites, such as Tagamaucia, were evidently too humid to support fire.

\section{Early human impact}

Most records show distinct changes in vegetation around 2700-3100 years ago, usually associated with a sustained increase in charcoal. Yacata Pond provides the best record for human impact and slope instability so far and provides a model for accelerated slope erosion that infilled the depositional basin after $2700 \mathrm{cal}$. BP (Figure 33). Bonatoa and Sari also have distinctive changes, but were undergoing successional changes at the time that may obscure the level of human impact. Other regional pollen studies that provide persuasive evidence for significant human impact accompanying human arrival are from Avai' o'vuna in Tonga (Fall 2005), Mangaia Island in the Cook Islands (Ellison 1994; Kirch and Ellison 1994), St Louis Lac, Plum and Koumac in New Caledonia (Stevenson and Dodson 1995; Stevenson 1998; Hope et al. 1998) and Aneityum in Vanuatu (Hope and Spriggs 1982). At all these sites the arrival of humans radically changed the catchment forest vegetation to shrublands, talasiga or grasslands, which was accompanied by the influx of inorganic sediment into lakes or swamps.

An increase and sustained signal of fire in these landscapes is the best indicator of prehistoric human presence. Figure 34 summarises the charcoal (fire) histories of representative palaeoecological sites from Fiji, New Caledonia, Vanuatu and Tonga based on our best estimate of their chronologies. In general, fire becomes a constant at most sites after $2700 \mathrm{cal}$. BP, but the records are quite variable and often show moderate or low charcoal until 800-1600 cal. BP, followed by an order-of-magnitude increase in charcoal influx. In sites such as Volivoli, Yacata, Nabuni and possibly Keitera on Totoya Island, the major increase in charcoal is associated with slope losses. Once sites stabilise, the inorganic sediment and charcoal influx may fall. This may reflect increased surface cover by grass and ferns that reduces charcoal transport from burned slopes into basins. It would be premature to tie the records directly to the amount of burning, and hence human activity, in the catchments or in the swamps.

While all near-coastal sites in Fiji record abrupt changes in sedimentation associated with a decline in primary forest, increases in secondary and disturbance taxa and increased grass, ferns and charcoal, the dating in several cases is problematic. Several sites seem to have convincing evidence for fire-caused vegetation change, but the onset of this disturbance is much older than the established archaeological record for Fiji. The Volivoli Lagoon record shows distinct changes in vegetation and sedimentation associated with increased fire, which commenced around 5100 cal. BP. The transition from peat to clay at Mudflat on Mago Island around $5000 \mathrm{cal}$. BP may indicate a hiatus in deposition after $5000 \mathrm{cal}$. BP until burial by slopewash at an unknown date. However the alluvial muds that bury this swamp are the result of burning that could be ascribed to human-caused disturbance. AMS dating of individual burned particles will be necessary to obtain more precise dating for the peat-to-clay transition event.

Both Soleve, on Kaibu Island, and Navatu, on Viti Levu, record young dates for the onset of post-settlement disturbance, at around $1200 \mathrm{cal}$. BP, from the top of organic sediments buried 


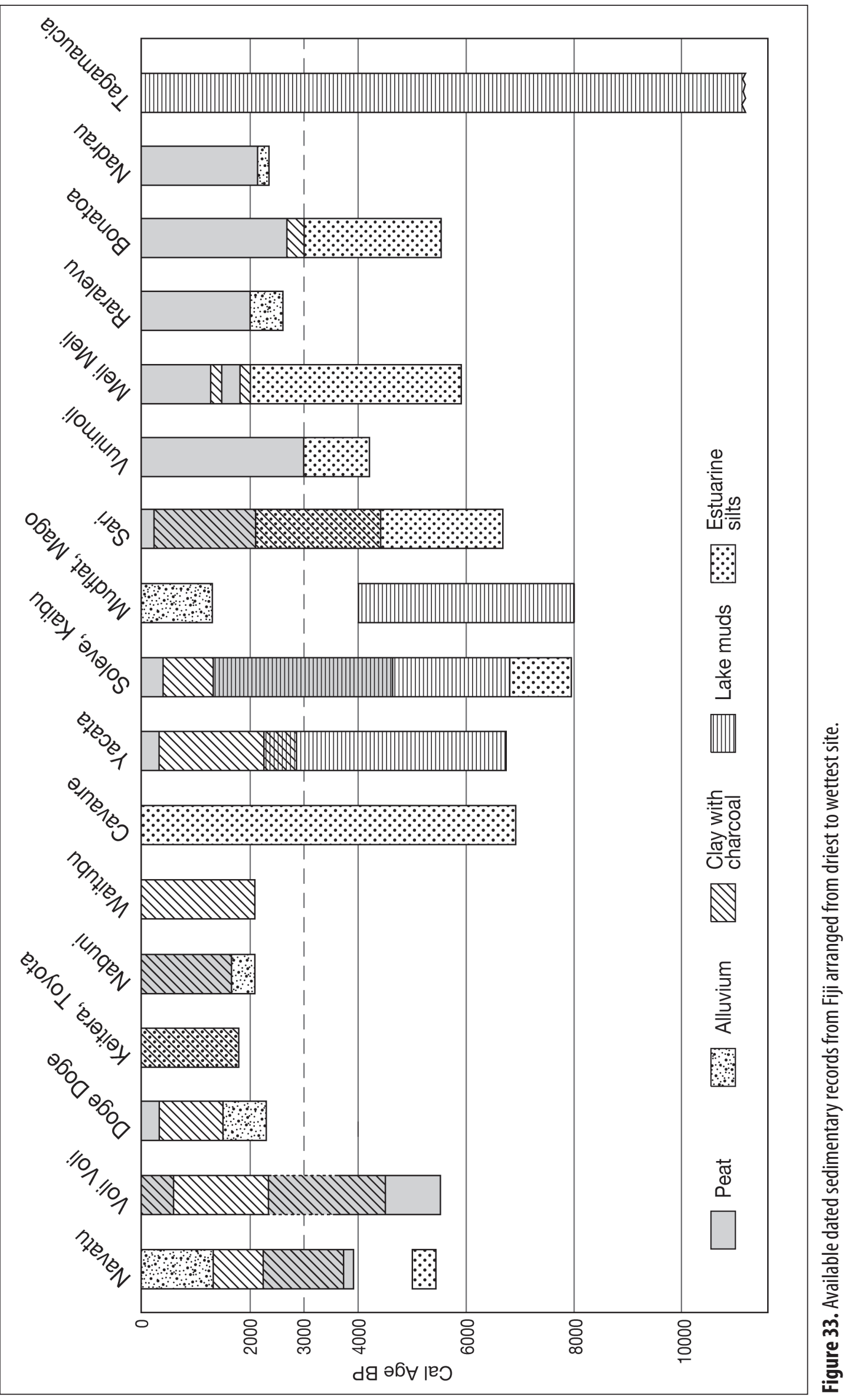




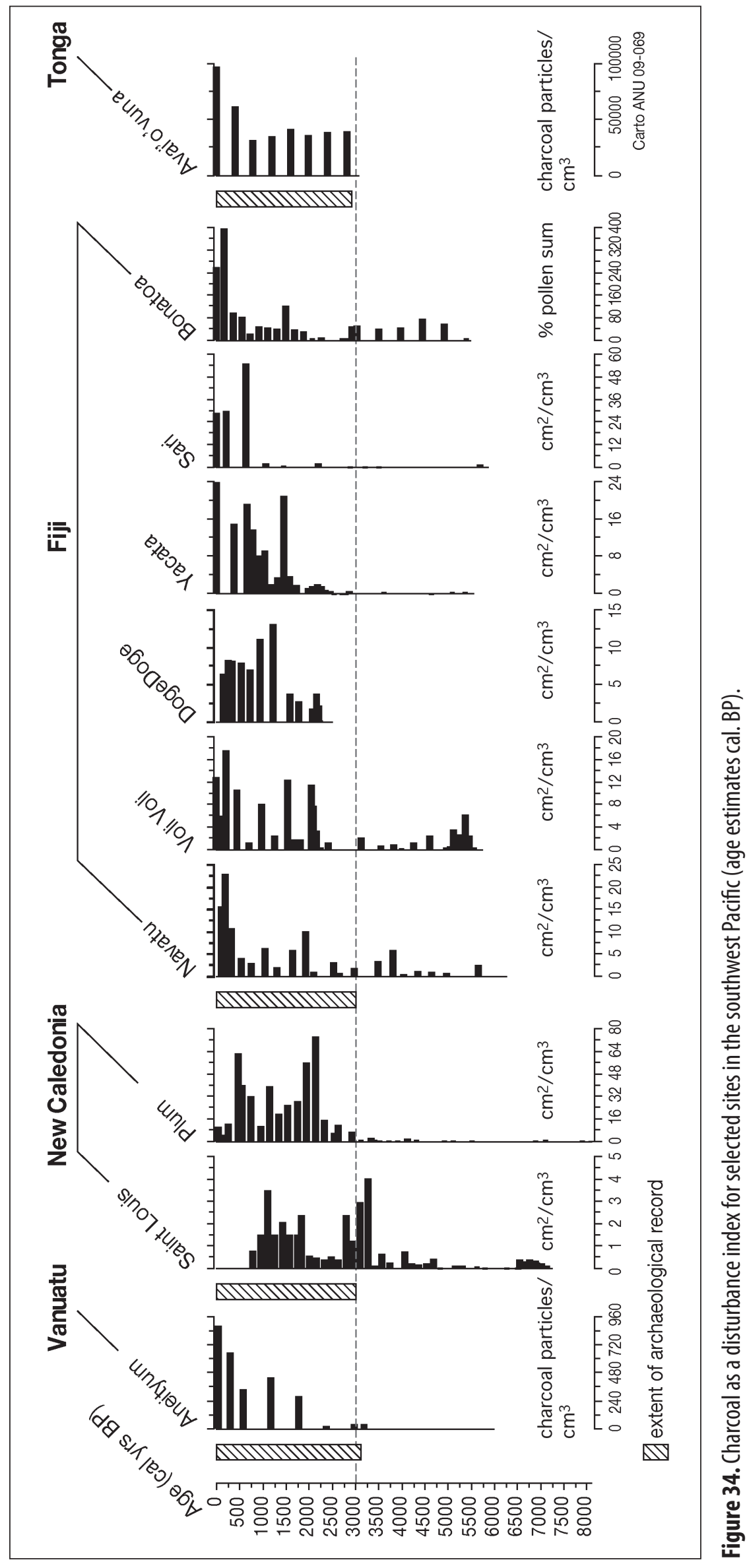


by alluvial infills. At both sites, however, the overlying alluvial clays return older dates because they have probably incorporated older organic material from their catchments. Anderson (1994, 1995) has noted that human settlement is often associated with surface erosion, which can result in anomalously old dates for human colonisation.

Hence, problems with dating the pollen sections remain. Anelcahat Swamp, Aneityum, Vanuatu, has a clear association of increased fire, vegetation change and burial of a peatland by terrigenous red clays. Dating of the organic components in the base of the clay resembles

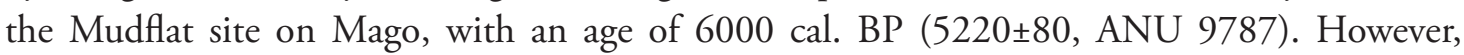
extrapolation of peat accumulation rates from the base of the core suggests an age of $2750 \mathrm{cal}$. $\mathrm{BP}$ for the same level. This is in agreement with a date from the base of the clay from a pit on the side of the swamp of $3000 \pm 80$ BP (Hope and Spriggs 1982). The Anelcahat site may resemble St Louis Lac or Yacata, and a new section is currently being processed for macrofossils that can be directly dated.

\section{Landscape response 2200-1200 cal. BP}

While some sites, such as Yacata, indicate abrupt and lasting impacts soon after $2700 \mathrm{cal}$. BP, other sites, such as Bonatoa, record relatively low impact from initial settlement, followed by more widespread clearance and increased burning after 2200-1800 cal. BP. This age range also dates the probable clearance event at the source of the Sigatoka River that initiated swamp development at Nadrau around $2200 \mathrm{cal}$. BP. It may also coincide with the major slope collapse on Lakeba Island, which is estimated to have taken place about 200-300 years after slope erosion attributable to fire and clearance along the lower Sigatoka appears to have initiated Doge Doge Swamp by stream blockage. These dates support the hypothesis that parts of Fiji had started to be altered soon after human arrival, but that many of the major transformations took place 500-1100 years after colonisation.

Building on his work at Aneityum, Spriggs (1997) postulated that the erosion of slopes due to fire and forest clearance in the Pacific led to the construction of lowland silt plains that were highly suitable for cropping. He speculates that some of the destruction may in fact have been intentional, resulting in greater net agricultural productivity despite forest loss and the spread of talasiga on slopes. Fiji possessed widespread lowland alluvial plains before settlement, but the subsequent erosion (and possible sea-level fall) did convert numerous estuarine swamps into alluvial valley floors that were used for agriculture. There is a wide range of dates for the major alluviation phase in Fiji, but it is true that it seems to be a phase with definite limits. For example, Volivoli appears to stabilise, with lower inputs of slope materials in the past 1000 years, and similar observations apply to Yacata. While this may be tied to changes in human impact, it is also possible that better-organised gardening and exhaustion of erodible sediment contributed to stabilisation.

In some cases, the result of deforestation was to convert valley floors to swampland. Doge Doge is a relatively early peatland that was created as a result of levee building, possibly by sediments released by vegetation clearance. Removal of the forest can increase water yields and this may contribute to the initiation of swamp conditions. Other examples include Nadrau and the Lakeba Island sites, where very rapid sediment accumulation was followed by rapid peat build up or slower accumulation of organic-rich clay. Lakutu and Mela are near coastal swamps on Guadacanal Island, Solomons, which experienced an initial clay influx with charcoal around 3000 years ago with the loss of forest cover (Haberle 1996). The sites then developed into peat bogs. Similarly, sites on Erromango and Aneityum Islands, Vanuatu, developed organic deposits after clearance around 1800-2000 years ago (Hope et al. 1998). It is possible that the Korowaiwai peatlands at $130 \mathrm{~m}$ altitude in central Vanua Levu are of this type. 


\section{Marine and climatic influences}

The transition from estuary to swamp, and the variable influxes of sediment associated with lateHolocene burning, tend to conceal possible impacts of climate and minor changes in sea level on the vegetation reconstructed from pollen diagrams. The only undisturbed site, Tagamaucia, is buffered climatically by extremely high rainfall and the record is disturbed by the development of floating sedge islands in the last millennium, so minor changes in forest taxa cannot be attributed to climate changes on the scale of minor temperature and rainfall fluctuations. The most sensitive sites to aridity and natural fires are Volivoli and Navatu. If our tentative discovery of a changed fire regime around $5000 \mathrm{cal}$. BP is correct, it may reflect increased variability in climate and more extreme El Niño fluctuations after that time, as postulated by Gagan et al. (2004).

The falls in local sea level which are suggested between 4500 and 2000 cal. BP by Dickinson (2001) and Nunn (2007) seem to have accelerated vegetation successions and possibly curtailed swamp accumulation in some coastal sites. It is a moot point whether, as Nunn (2007) claims, this allowed human occupation of valley floors, as these locations were often buried by an influx of slope alluvium, which also raised the sites above sea level, and storm waves were impeded by more emergent offshore barriers.

The resolution is low for the pollen data from Fiji, but there appears to be no indication of any widespread and abrupt changes around 700 years ago that might support the well-publicised 'AD 1300 event' proposed by Nunn (2007) and Kumar et al. (2006). Clark and Cole (1997) note that the Totoya sequences cover both the Little Ice Age and a possible warm period with no obvious changes. While we acknowledge the warnings of Nunn (1991, 1994) against assigning environmental changes to human agency, we suggest that minor sea level and climate events are unlikely to be the cause of the vegetation and sediment sequences and charcoal records we have found in many parts of Fiji.

\section{Conclusion}

Virtually all of the research on vegetation history in Fiji has been undertaken to compare prehuman vegetation and landscape processes with those after human settlement. Although more than 20 pollen diagrams and charcoal records exist, relatively few sites provide unproblematic sequences recording human settlement and change to the vegetation. Some sites are in areas where humans have had little impact, while others have sedimentary breaks or dating problems. Despite this, the present study shows that there is great potential for high-resolution palaeoecology using well-dated multi-proxy work. The results demonstrate that the landscape history is complex, with individual responses at each site examined.

Most sedimentary basins are created as a response to sea-level stabilisation around 6000$7000 \mathrm{cal}$. BP. Fire, apparently linked to increases in catchment erosion, is seen in some sites after $5000 \mathrm{cal}$. BP. In broad terms, smaller islands and the dry sides of the large islands respond to increased fire at the time of human arrival soon after $3000 \mathrm{cal}$. BP. After $2200 \mathrm{cal}$. BP, clearance and conversion to scrub and talasiga is widespread. More humid sites, while recording increased burning, maintain forest cover, although secondary species become more common, particularly after 1700-2000 cal. BP. Some swamps are caused by levee damming and possibly increased runoff within the past 2400 years, while others are buried by alluvium. The palaeoenvironmental records assembled here illustrate the potential sedimentary basins have to provide independent evidence of human impact, but they also illustrate the complexity inherent in this approach, particularly that human impact is not necessarily a straightforward and homogeneous historical process. Evidence for a marked environmental change associated with the Little Ice Age was not noted, and, in fact, several sites record reduced inorganic inputs after 800 years ago. 


\section{References}

Anderson, A.J. 1994. Palaeoenvironmental evidence of island colonization: A response. Antiquity 68: 845-847.

Anderson, A.J. 1995 Current approaches in East Polynesian colonisation research. Journal of the Polynesian Society 104: 110-132.

Anderson, A., Burley, D., Clark, G., de Biran, A., Dickinson, W., Hope, G. and Roberts R. 2006. The times of sand: Sedimentary history and archaeology at the Sigatoka Sand Dunes, Fiji. Geoarchaeology 21: 131-154.

Ash, J. 1992. Vegetation ecology of Fiji: Past, present, and future perspectives. Pacific Science 46: 111-127.

Burley, D.V. and Dickinson, W.R. 2004. Late Lapita occupation and its ceramic assemblage at the Sigatoka Sand Dune Site, Fiji and their place in oceanic prehistory. Archaeology in Oceania 39: $12-25$.

Clark, G. 2000. Post-Lapita Fiji: Cultural transformation in the mid-sequence. Unpublished PhD thesis, Australian National University.

Clark, G., Anderson, A. and Matararaba, S. 2001. The Lapita site at Votua, northern Lau Islands, Fiji. Archaeology in Oceania 36: 134-145.

Clark, J.T. and Cole, A.O. 1997. Environmental change and human prehistory in the Central Pacific: Archaeological and palynological investigations on Totoya Island, Fiji. Report to the Fiji Museum, Suva.

Clark, J.T., Cole, A.O. and Nunn, P.D. 1999. Environmental change and human prehistory on Totoya Island, Fiji. In: Lilley, I. and Galipaud, J-C. (eds), Le pacifique de 5000 à 2000 avant le présent. Suppléments à l'histoire d'une colonisation. The Pacific from 5000 to 2000 BP. Colonisation and transformations, pp 227-240. Actes du colloque Vanuatu, 31 Juillet - 6 Aout 1996. Editions de l'ORSTOM. Collection Colloques et séminaires, Paris.

Clark, G. and Hope, G. 2001. Archaeological and palaeoenvironmental investigations on Yacata Island, northern Lau, Fiji. Domodomo 13(2): 29-47.

Cole, A.O. 1996. A dynamical systems framework for modelling plant community organisation. Unpublished PhD thesis, Massey University.

Dickinson, W.R. 2001. Paleoshoreline record of relative Holocene sea levels on Pacific Islands. Earth Science Reviews 5: 191-234.

Dickinson, W.R. 2009. Pacific atoll living: How long already and until when? GSA Today 19(3): 4-10. doi: 10.1130/GSATG35A.1.

Dickinson, W.R., Burley, D.V., Nunn, P.D., Anderson, A., Hope, G., de Biran, A., Burke C. and Matararaba, S. 1998. Geomorphic and archaeological landscapes of the Sigatoka Dunes Site, Viti Levu, Fiji: Interdisciplinary investigations. Asian Perspectives 37: 1-31.

Ellison, J.C. 1994. Palaeo-lake and swamp stratigraphic records of Holocene vegetation and sea level changes, Mangaia, Cook Islands. Pacific Science 48: 1-15.

Fall, P.L. 2005. Vegetation change in the coastal-lowland rainforest at Avai'o'vuna Swamp, Vava'u, Kingdom of Tonga. Quaternary Research 64: 451-459.

Gagan, M.K., Hendy, E.J., Haberle, S.G. and Hantoro, W. 2004. Post-glacial evolution of the IndoPacific Warm Pool and El Niño-Southern Oscillation. Quaternary International 118-119: 127-143.

Gifford, E.W. 1951. Archaeological excavations in Fiji. University of California Anthropological Records 13: $189-288$.

Haberle, S. 1996. Explanations for palaeoecological changes on the northern plains of Guadalcanal, Solomon Islands: The last 3200 years. Holocene 6(3): 333-338.

Hope, G.S. 1996. Quaternary change and historical biogeography of Pacific Islands. In: Keast, A. and Miller, S.E. (eds), The origin and evolution of Pacific Island biotas, New Guinea to Eastern Polynesia: Patterns and process, pp. 165-190. SPB Publishing, Amsterdam.

Hope G.S., O’Dea, D. and Southern, W. 1998. Holocene vegetation histories in the Western Pacific alternative records of human impact. In: Lilley, I. and Galipaud, J-C. (eds), Le pacifique de 5000 à 2000 avant le présent. Suppléments à l'histoire d'une colonisation. The Pacific from 5000 to 2000 BP. 
Colonisation and transformations. Actes du colloque Vanuatu, 31 Juillet - 6 Aout 1996. Editions de l'ORSTOM. Collection Colloques et séminaires, Paris.

Hope, G.S. and Pask, J. 1998. Tropical vegetational change in the late Pleistocene of New Caledonia. Palaeogeography, Palaeoclimatology, Palaeoecology 142: 1-21.

Hope, G.S. and Spriggs, M.J.T. 1982. A preliminary pollen sequence from Aneityum Island, Southern Vanuatu. Bulletin of the Indopacific Prehistory Association 3: 88-94.

Hughes, P.J., Hope, G.S., Latham M. and Brookfield, M. 1979. Prehistoric man-induced degradation of the Lakeba landscape: evidence from two inland swamps. In: Brookfield, H.G. (ed), Lakeba: Environmental change, population and resource use, pp. 93-111. UNESCO/UNFPA Island Reports 5.

Kirch, P.V. and Ellison, J.C. 1994. Palaeoenvironmental evidence for human colonisation of remote oceanic islands. Antiquity 68: 310-321.

Kumar, R., Field, J.S., de Biran, A. 2006. Human responses to climate change around AD 1300: A case study of the Sigatoka Valley, Viti Levu Island, Fiji. Quaternary International 151: 133-143.

Latham, M. 1986. Alteration et pédogenése sur roches ultrabasiques en Nouvelle-Calédonie. ORSTOM, Paris.

Latham, M., Hughes, P.J., Hope, G. and Brookfield, M. 1983. Sedimentation in the swamps of Lakeba and its implications for erosion and human occupation of the island. In: Latham, M. and Brookfield, H.C. (eds), The eastern islands of Fiji - a study of the natural environment, its use and man's influence on its evolution, pp. 103-120. Travaux et Documents de l'ORSTOM, Paris. 162.

Mueller-Dombois, D. and Fosberg, F.R. 1998. Vegetation of the tropical Pacific Islands. Springer Press, New York.

Nunn, P.D. 1991. Human and non-human impacts on Pacific island environments. Environment and Policy Institute East West Center Occasional. Paper 13.

Nunn, P.D. 1994. Beyond the naive lands: Human history and environmental change in the Pacific Basin. In: Wadell, E. and Nunn, P.D. (eds), The margin fades: Geographical itineraries in a world of islands, pp. 5-27. Institute of Pacific Studies, USP, Suva.

Nunn, P.D. 2007. Climate, environment and society in the Pacific during the last millennium. Elsevier, Amsterdam.

Nunn, P.D. and Peltier, W.R. 2001. Far-field test of the ICE-4G (VM2) model of global isostatic response to deglaciation: Empirical and theoretical Holocene sea level reconstructions for the Fiji Islands, Southwest Pacific. Quaternary Research 55: 203-214.

Nunn, P.D., Thaman, R.R., Duffy, L., Finikaso, S., Ram, N. and Swamy, M. 2001. Age of a charcoal band in fluvial sediments, Keiyasi, Sigatoka Valley, Fiji: Possible indicator of a severe drought throughout the Southwest Pacific 4500-5000 years ago. South Pacific Journal of Natural Science 19: 5-10.

Parry, J.T. 1987. The Sigatoka Valley - pathway into prehistory. Bulletin of the Fiji Museum 9.

Shepherd, M.J. 1990. The evolution of a moderate energy coast in Holocene time; Pacific Harbour, Viti Levu, Fiji. New Zealand Journal of Geology and Geophysics 33: 547-556.

Southern, W. 1986. The Late Quaternary environmental history of Fiji. Unpublished PhD thesis, Australian National University.

Spriggs, M.J.T. 1997. The island Melanesians. Blackwell, Oxford.

Stevenson J. 1998. Human impact from the palaeoenvironmental record of New Caledonia. In: Lilley, I. and Galipaud, J-C. (eds), Le pacifique de 5000 à 2000 avant le présent. Suppléments à l'histoire d'une colonisation. The Pacific from 5000 to 2000 BP. Colonisation and transformations, pp. 251-259. Actes du colloque Vanuatu, 31 Juillet - 6 Aout 1996. Editions de l'ORSTOM. Collection Colloques et séminaires, Paris.

Stevenson, J. and Dodson, J.R. 1995. Palaeoenvironmental evidence for human settlement of New Caledonia. Archaeology in Oceania 30: 36-41.

Stevenson, J. and Hope, G.S. 2005. A comparison of late Quaternary forest changes in New Caledonia and northeastern Australia. Quaternary Research 64: 372-383.

Stevenson, J., Dodson, J.R. and Prosser, I.P. 2001. A late Quaternary record of environmental change and human impact from New Caledonia. Palaeogeography, Palaeoclimatology, Palaeoecology 168: 97-123.

Ward R.G. 2002. Land use on Mago, Fiji: 1865-1882. The Journal of Pacific History 37(1): 103-108. 